University of Nebraska - Lincoln

DigitalCommons@University of Nebraska - Lincoln

2012

\title{
Modeling the spatial and temporal heterogeneity of deforestation- driven carbon emissions: the INPE-EM framework applied to the Brazilian Amazon
}

\author{
Ana Paula Dutra Aguiar \\ Brazilian Institute for Space Research, ana.aguiar@inpe.br \\ Jean Pierre Ometto \\ Brazilian Institute for Space Research \\ Carlos Nobre \\ Brazilian Institute for Space Research \\ David Montenegro Lapola \\ Universidade Estadual Paulista, dmlapola@rc.unesp.br \\ Claudio Almeida \\ Brazilian Institute for Space Research \\ See next page for additional authors
}

Follow this and additional works at: https://digitalcommons.unl.edu/nasapub

Dutra Aguiar, Ana Paula; Ometto, Jean Pierre; Nobre, Carlos; Montenegro Lapola, David; Almeida, Claudio; Vieira, Ima Célia; Soares, Joao Vianei; Alvala, Regina; Saatchi, Sassan; Valeriano, Dalton; and CastillaRubio, Juan Carlos, "Modeling the spatial and temporal heterogeneity of deforestation-driven carbon emissions: the INPE-EM framework applied to the Brazilian Amazon" (2012). NASA Publications. 109. https://digitalcommons.unl.edu/nasapub/109

This Article is brought to you for free and open access by the National Aeronautics and Space Administration at DigitalCommons@University of Nebraska - Lincoln. It has been accepted for inclusion in NASA Publications by an authorized administrator of DigitalCommons@University of Nebraska - Lincoln. 


\section{Authors}

Ana Paula Dutra Aguiar, Jean Pierre Ometto, Carlos Nobre, David Montenegro Lapola, Claudio Almeida, Ima Célia Vieira, Joao Vianei Soares, Regina Alvala, Sassan Saatchi, Dalton Valeriano, and Juan Carlos Castilla-Rubio 


\title{
Modeling the spatial and temporal heterogeneity of deforestation-driven carbon emissions: the INPE-EM framework applied to the Brazilian Amazon
}

\author{
ANA PAULA DUTRA AGUIAR*, JEAN PIERRE OMETTO*, CARLOS NOBRE*, \\ DAVID MONTENEGRO LAPOLA $\dagger$, CLAUDIO ALMEIDA,+ IMA CÉLIA VIEIRA \\ JOÃO VIANEISOARESף, REGINA ALVALA*, SASSAN SAATCHI\|, DALTON VALERIANOף \\ and JUAN CARLOS CASTILLA-RUBIO** \\ *Earth System Science Center (CCST), Brazilian Institute for Space Research (INPE), Av dos Astronautas 1758, 12227-010, São \\ José dos Campos, SP Brazil, †Laboratório de Ciência do Sistema Terrestre (LabTerra), Department of Ecology, Universidade \\ Estadual Paulista (UNESP), Av. 24A, 1515, 13506-900, Rio Claro, SP Brazil, \$Amazon Regional Center (CRA), Brazilian \\ Institute for Space Research (INPE), Parque de Ciência e Tecnologia do Guamá, Av. Perimetral 2651, CEP 66077-830, Belém, PA \\ Brazil, §Coordenação de Pesquisa e Pós-Graduação, Museu Paraense Emilio Goeldi (MPEG), Av. Magalhães Barata 376 - São \\ Braz, CEP: 66040-170, Belém, PA Brazil, 『Earth Observation Coordination (OBT), Brazilian Institute for Space Research (INPE), \\ Av dos Astronautas 1758, 12227-010, São José dos Campos, SP Brazil, ||Jet Propulsion Laboratory, NASA, 4800 Oak Grove Drive, \\ Pasadena, CA 91109, USA, **Planetary Skin Institute, Silicon Valley, CA USA
}

\begin{abstract}
We present a generic spatially explicit modeling framework to estimate carbon emissions from deforestation (INPE-EM). The framework incorporates the temporal dynamics related to the deforestation process and accounts for the biophysical and socioeconomic heterogeneity of the region under study. We build an emission model for the Brazilian Amazon combining annual maps of new clearings, four maps of biomass, and a set of alternative parameters based on the recent literature. The most important results are as follows: (a) Using different biomass maps leads to large differences in estimates of emission; for the entire region of the Brazilian Amazon in the last decade, emission estimates of primary forest deforestation range from 0.21 to $0.26 \mathrm{Pg} \mathrm{C} \mathrm{yr}^{-1}$. (b) Secondary vegetation growth presents a small impact on emission balance because of the short duration of secondary vegetation. In average, the balance is only $5 \%$ smaller than the primary forest deforestation emissions. (c) Deforestation rates decreased significantly in the Brazilian Amazon in recent years, from $27 \mathrm{Mkm}^{2}$ in 2004 to $7 \mathrm{Mkm}^{2}$ in 2010. INPE-EM process-based estimates reflect this decrease even though the agricultural frontier is moving to areas of higher biomass. The decrease is slower than a non-process instantaneous model would estimate as it considers residual emissions (slash, wood products, and secondary vegetation). The average balance, considering all biomass, decreases from 0.28 in 2004 to $0.15 \mathrm{Pg} \mathrm{C} \mathrm{yr}^{-1}$ in 2009 ; the nonprocess model estimates a decrease from 0.33 to $0.10 \mathrm{Pg} \mathrm{C} \mathrm{yr}^{-1}$. We conclude that the INPE-EM is a powerful tool for representing deforestation-driven carbon emissions. Biomass estimates are still the largest source of uncertainty in the effective use of this type of model for informing mechanisms such as REDD+. The results also indicate that efforts to reduce emissions should focus not only on controlling primary forest deforestation but also on creating incentives for the restoration of secondary forests.
\end{abstract}

Keywords: Amazonia, carbon emissions, deforestation, LUCC, REDD, secondary forests

Received 4 November 2011 and accepted 21 May 2012

\section{Introduction}

Deforestation in tropical regions is one of the key components of climate change concerns (Le Quéré et al., 2009; van der Werf et al., 2009). Forest cover removal releases $\mathrm{CO}_{2}$ and other greenhouse gases as a result of tree burning, followed by the gradual decomposition of the forest biomass left on the ground while pasture-

Correspondence: Ana Paula D. Aguiar, tel. + 551232087 125, fax + 551232087 126, e-mail: ana.aguiar@inpe.br lands or crop plantations are established. The regrowth of secondary vegetation on abandoned agricultural/ pasture land may constitute an important component of the regional carbon balance because this growth removes $\mathrm{CO}_{2}$ from the atmosphere, transferring it to vegetation biomass and soil carbon compartments (Ramankutty et al., 2007).

Emissions derived from such processes are considered one of the most uncertain components of the global carbon cycle (Le Quéré et al., 2009; Ometto et al., 2011), and several studies have attempted to estimate 
the contribution of land cover changes and deforestation to the global carbon budget. For the period from 1981 to 1990, Fearnside (2000) calculated a total of 2.4 $\mathrm{Pg} \mathrm{C} \mathrm{yr}^{-1}$ for the carbon emissions resulting from tropical deforestation in the world. For the 1990s, Houghton (2003a) estimated global land cover change carbon emissions to be $2.2 \mathrm{Pg} \mathrm{C} \mathrm{yr}^{-1}$, a value that represented almost $35 \%$ of the $6.4 \mathrm{Pg} \mathrm{C} \mathrm{yr}^{-1}$ derived from fossil fuel emissions in that decade. In contrast, DeFries et al. (2002) and Achard et al. (2004) estimated values of $0.9{\mathrm{PgC} \mathrm{yr}^{-1}}^{-1}$ and $1.1 \mathrm{Pg} \mathrm{C} \mathrm{yr}^{-1}$, respectively, for the same period, highlighting the level of uncertainty of this component of the global carbon budget. Using revised rates of land-use change for the period from 1960 to 2000, Houghton (2008) lowered the estimates of average net flux from $\sim 2.2 \mathrm{PgC} \mathrm{yr}^{-1}$ (Houghton,

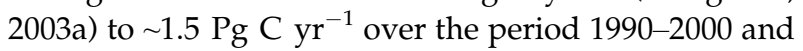
estimated a value of $1.47 \mathrm{Pg} \mathrm{C} \mathrm{yr}^{-1}$ for the period 2000 -2005. In contrast, Malhi (2010) estimated tropical biome conversion to be a source of $1.3 \pm 0.2{\mathrm{Pg} \mathrm{C} \mathrm{yr}^{-1}}^{-1}$ to the atmosphere from both 1990-1999 and 2000-2005. These authors also suggested that this value may have dropped to $1.0 \mathrm{Pg} \mathrm{C} \mathrm{yr}^{-1}$ after 2005 if a recent drop in deforestation rates in Brazil is taken into account (Loarie et al., 2009). A more recent estimate of gross emission from deforestation over pantropical regions from a spatially refined and systematic approach predicted even lower value of $0.8 \mathrm{Pg} \mathrm{C} \mathrm{yr}^{-1}(0.57-1.22)$ over the 2000-2005 period, approximately $10 \%$ of the fossil fuel emissions over the same period (Harris et al., 2012).

Le Quéré et al. (2009) also pointed out that, due to increased fossil fuel emissions and below-average deforestation emissions, the relative contribution of LUC (Land-use change) to total anthropogenic $\mathrm{CO}_{2}$ emissions decreased from $20 \%$ in $1990-2000$ to $12 \%$ in 2008. LUC $\mathrm{CO}_{2}$ emissions are largely attributed to deforestation in tropical regions, mainly in developing countries like Brazil and Indonesia, but they also include logging and intensive cultivation of cropland soils. According to Le Quéré et al. (2009), the total $\mathrm{CO}_{2}$ emissions from fossil fuel combustion and LUC in 2008 was $9.9 \pm 0.9 \mathrm{Pg} \mathrm{C} \mathrm{yr}^{-1}$, with LUC corresponding to 1.2 Pg C of this total. However, although LUC emissions were the smaller factor, their uncertainty is greater than the uncertainty associated with fossil fuel emissions ( $\pm 0.7 \mathrm{PgC} \mathrm{yr}^{-1}$ and $\pm 0.5 \mathrm{PgC} \mathrm{yr}^{-1}$, respectively). Pan et al. (2011) estimated a source of $1.3 \pm 0.7 \mathrm{Pg} \mathrm{C} \mathrm{yr}^{-1}$ from tropical land-use change, consisting of a gross tropical deforestation emission of $2.9 \pm 0.5 \mathrm{Pg} \mathrm{C} \mathrm{yr}^{-1}$ partially compensated by a carbon sink in tropical forest regrowth of $1.6 \pm 0.5 \mathrm{Pg} \mathrm{C} \mathrm{yr}^{-1}$.

The high uncertainty associated with estimates of tropical deforestation carbon emissions reflects both the complexity of the deforestation process itself and the variety of methodologies and data sources used in the calculations (Ometto et al., 2005; Ramankutty et al., 2007). Therefore, a great challenge in the climate change community is to produce reliable and systematic data regarding carbon emissions resulting from deforestation in tropical regions. These data are necessary not only from a scientific perspective but also to support appropriate monitoring, reporting and verification capabilities for emissions reduction targets and mitigation schemes in different countries.

A critical issue in reducing such uncertainties is the availability of reliable, spatially distributed information on deforestation and biomass. In comparing previous estimates of tropical deforestation carbon emissions, Ramankutty et al. (2007) argued that to reduce uncertainties, it is also important to correctly represent the deforestation process itself, which includes the following factors: (1) the full land cover dynamics during and following deforestation (for instance, how the trees are actually removed, how long it takes to completely clear the land, and where and after how long agricultural land is abandoned), (2) the explicit inclusion of historical land cover change for several decades (to account for previous deforestation decomposition and vegetation recovery processes), (3) an accurate estimate of the fate of cleared carbon (for instance, how much is extracted by the forestry sector, how the timber is used and how long it takes to be released to the atmosphere after deforestation, how much is immediately released by fire, and how much dead biomass is left on the ground to decompose gradually).

We argue that another key to represent correctly the deforestation process is to consider the socioeconomic and biophysical heterogeneity of a given region. In the Brazilian Amazon, for example, due to intense human occupation in the last five decades, approximately $18 \%$ of the original rainforest has been removed (INPE, 2011a). The Brazilian Amazon is a largely heterogeneous region with respect to its biophysical characteristics, its occupation history and socioeconomic, political and institutional aspects (Alves, 2002; Becker, 2004; Aguiar et al., 2007; Alves et al., 2009). The regional economy and society today constitute a complex mosaic of actors and conflicting interests (Araújo \& Lená, 2010). The rural population includes traditional riverside populations, small farmers, cattle ranchers, mechanized grain producers, and large companies from different sectors (e.g., mining, cosmetics, forestry) that extract and industrialize natural resources. Set in different production systems (Becker, 2004; Costa, 2008, 2009), these actors employ characteristic practices during the deforestation process. These differences include the speed of the process used to remove or explore the primary forest, which depends on the capital and the 
techniques employed. It may or may not includethe use of secondary vegetation as part of a given production system (Perz \& Skole, 2003; Costa, 2004; Mello et al., 2011).

In this context, we designed a new emission modeling framework (INPE-EM) based on the bookkeeping model developed initially by Houghton et al. (2000) and Houghton (2003b). The framework is spatially explicit, as in Loarie et al. (2009), to account for the spatial distribution of biomass and deforestation while also taking into account the intra-regional diversity of landuse change practices regarding pristine and secondary vegetation removal dynamics. The INPE-EM is a generic framework that can potentially be applied to any tropical forest area if the correct parameters are provided. As an initial application of the framework, we build a model to estimate annual carbon emissions from deforestation in the Brazilian Amazon. For this estimation, we use spatially explicit deforestation data from 2002 to 2009 (INPE, 2011a,b,c) and non-spatially explicit historical deforestation rates from 1961 to 2001. We compare four different biomass sources (Saatch et al., 2007; Nogueira et al., 2008; MCT, 2010; Saatchi et al., 2011a) and alternative sets of parameters to explore key deforestation process uncertainties.

The article is organized as follows. Section 2.1 describes the INPE-EM framework, and Section 2.2 details parameterization and data sources for its application to the Brazilian Amazon. Section 3 presents the carbon emission estimates resulting from alternative model runs. Section 4 discusses the results of the article with respect to both the deforestation-driven carbon emissions in the Brazilian Amazon and the applicability of the generic INPE-EM.

\section{Material and methods}

\section{INPE-EM framework}

This section describes the INPE-EM framework at the conceptual level, which was based on work published by Houghton et al. (2000). The original model was modified to include the spatial dimension and account for intra-regional biophysical and socioeconomic heterogeneity. The INPE-EM allows the creation of application models at different spatial and temporal scales, combining a spatial and a non-spatial mode:

- The 'Spatial Mode' requires a geographical database composed of regular cells at a spatial scale adequate for the study area application. This mode is applicable for the time period in which spatially explicit vegetation removal (forest to clear-cut deforestation) data are available (real or projected - to permit future scenario analysis when necessary). The spatial database must contain information about the percentage of each cell that was deforested in each year, the average aboveground biomass for each cell, and other necessary parameters describing the heterogeneity of the region. Emissions are computed for a given year for each cell, and the total emission is given by the sum of all cells.

- For the time period for which only non-spatial deforestation rates are available, we use INPE_EM in the 'Non-spatial Mode'. This is necessary to account for lagging contributions of the past (for instance, slash decay emissions, secondary vegetation absorption, and emission), which are summed with the results of the spatial mode. The behavior of the model is exactly the same in both modes: the non-spatial model is equivalent to using a regular grid composed of a single cell.

Figure 1 illustrates the overall INPE-EM structure, which is composed of two independent components: (1) Primary Forest, which represents the vegetation removal process from the original forest cover, and (2) Secondary Forest, which represents the process of the regeneration of the vegetation following the abandonment of deforested areas and the probable subsequent removal of at least part of this secondary vegetation for agricultural purposes, as described below.

Primary forest component. For each year, this model component uses the new deforested area in a given cell to compute the removed aboveground biomass (AGB). This amount of AGB is converted to carbon (C) by considering a mean content (\% of $\mathrm{C}$ given by carbonPercBiomass) in the plant biomass. The AGB carbon content is used to compute the belowground biomass (BGB) carbon content according to the BGB/AGB ratio (BGBPercAGB). Although some biomass data sources may report spatially explicit $B G B$, this is not always the case; thus, we opted to treat all data sources in a uniform way using the $B G B P \operatorname{erc} A G B$ average ratio. The framework keeps the AGB and BGB parameters for each data source as a Biomass submodel (see Table 2). The INPE-EM primary forest model component then considers that the estimated BGB will decay over the years according to an exponential decay rate (decayRateBGB). The deforested AGB carbon amount is divided into four possible paths, as proposed by Houghton et al. (2000): (1) The percentage removed as timber (percWood), assuming that the carbon in the derived wood products will be released to the atmosphere over the years with an exponential decay rate (decayRateWood), (2) The percentage of the remaining biomass, after timber exploration, that is burnt and released to the atmosphere immediately, in that same year (percFireFirstYear), (3) The percentage left on the ground to decompose (percSlash) with an exponential decay rate (decayRateSlash), which can burn again in subsequent years according to model parameter (slashFireCycle), (4) The percentage converted to elemental carbon by fire (percElementalCarbon), which decays at very slow rates (decayRateElem(arbon). To account for the heterogeneity of actors in the study area, INPE-EM allows such percentages to be spatially represented. Therefore, parameters can be cell specific, representing dominant land-use practices and trajectories. These parameters define a Primary Forest Submodel, and multiple submodels can be defined to test alternative values for a given application model.

The bookkeeping process functions as follows. The percentage of burnt carbon is added to that year's total emissions. All 


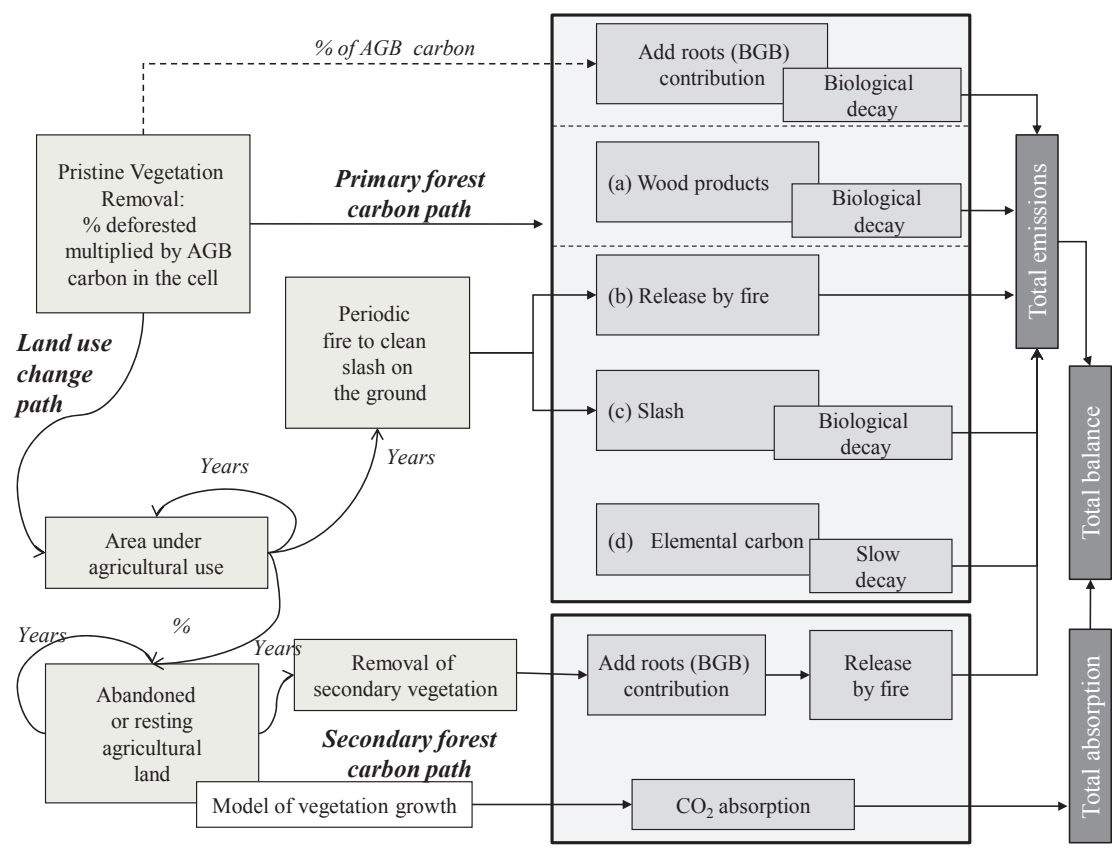

Fig. 1 INPE-EM: the conceptual model schematic representation.

the other parts decay at potentially different rates in a process that can require a different number of years. The model computes the amount of $C$ to be released in the subsequent years for items (a), (c) and (d) separately, as Fig. 1 illustrates, and stores the estimates in specific variables distributed over the years for each cell. This is a cumulative process that is repeated for every year simulated by the application model, with annual updates of such variables for items (a), (c), and (d). Therefore, in a given year, the total carbon emissions is the sum of immediate release by fire (b) and the previous year's gradual release accumulated through (a), (c), and (d) plus root decay (BGB).

Secondary growth component:. This model component represents different pathways in the dynamics of secondary vegetation using spatially distributed parameters, depending on land-use practices (Ramankutty et al., 2007). The parameters are the following: the percentage of the deforested area in a given cell that will be abandoned after some years of agricultural use (agriculturalliseCycle) and become secondary vegetation (percRegrow) according to the dominant land-use practice in that cell; the vegetation growth curve (modelRegrow) after abandonment; and the number of years, on average, it will take for that growing vegetation to be removed again. We use the parameter halfLife, based on the ideas of Almeida (2009), to estimate the secondary vegetation removal rate in each cell. The halfLife parameter indicates the number of years to remove $50 \%$ of the secondary vegetation (identified using remote sensing images), following an exponential curve. The model estimates the secondary vegetation removal rate for the following years using this exponential curve. The other necessary parameter is an estimate of the number of years of abandonment that must occur before the secondary vegetation can be recognized in remote sensing images (initialAbandonmentCycle). Parameter values for the Secondary Forest component are grouped as Secondary Forest (SF) submodels.

In this component, the bookkeeping process works as follows. On the basis of parameters agriculturalUseCycle, percRegrow, and modelRegrow, we estimate the regeneration rates and store them as absorbed carbon for each cell over the years, both above and belowground. Then we simulate the removal of part of this new vegetation according to the parameters initialAbandonmentCycle and halfLife and compute the amount emitted. The current INPE-EM secondary forest component considers all carbon (from BGB and ABG) to be released by fire during the year in which it is deforested, assuming that there is no biological decay or elemental carbon components. After removal, that vegetation is assumed to regenerate in subsequent years, simulating continuous abandonment, and use of the percentage of land defined by percRegrow.

For each year, INPE-EM computes the balance of all the carbon released and absorbed, combining the two components in the spatial or non-spatial mode, according to an application model. An INPE-EM application model consists of defining the temporal and spatial scale of the study, the deforestation data source and the three submodels (Biomass, PF and SF). Alternative submodels may be defined to explore process uncertainties in a given study area. Table 1 summarizes the parameters required in each submodel.

The current version of INPE-EM does not consider litter biomass or changes in soil carbon derived from deforestation. There is also no consideration of processes that can hold carbon for a longer time in the environment, such as land-use practices, soil conservation or microbial biomass growth rates. The current version also does not explicitly represent the gradual loss of biomass due to forest degradation process, which is associated with selective/cryptic logging and fire (DeFries et al., 2002; Foley et al., 2007), for the whole study 
Table 1 The INPE-EM parameters

\begin{tabular}{|c|c|c|c|c|c|}
\hline & Parameter & Description & Unit & $\begin{array}{l}\text { Spatial } \\
\text { dimension }\end{array}$ & $\begin{array}{l}\text { Temporal } \\
\text { dimension }\end{array}$ \\
\hline Deforestation & deforest & $\begin{array}{l}\text { New deforestation area in a } \\
\text { given period, according to model } \\
\text { temporal scale. }\end{array}$ & ha (hectars) & $\begin{array}{l}\text { mandatory } \\
\text { for the } \\
\text { spatial mode }\end{array}$ & $\begin{array}{l}\text { mandatory, } \\
\text { according to } \\
\text { the temporal } \\
\text { scale of the } \\
\text { model }\end{array}$ \\
\hline \multirow[t]{3}{*}{ Biomass } & $A G B$ & $\begin{array}{l}\text { Avarage pristine vegetation AGB } \\
\text { (above ground biomass) }\end{array}$ & Mgha $^{-1}$ & $\begin{array}{l}\text { mandatory for } \\
\text { the spatial } \\
\text { mode }\end{array}$ & no \\
\hline & carbonPercBiomass & $\begin{array}{l}\text { Carbon }(\%) \text { in dry biomass (mean of } \\
\text { several plant tissues) }\end{array}$ & $\%$ & no & no \\
\hline & $B G B P \operatorname{erc} A G B$ & $\begin{array}{l}\text { Percentage of AGB to consider as } \\
\text { BGB (bellow ground biomass) }\end{array}$ & $\%$ & optional & no \\
\hline \multirow[t]{9}{*}{$\begin{array}{l}\text { Primary } \\
\text { Forest }\end{array}$} & percWood & $\begin{array}{l}\text { AGB percentage removed as timber } \\
\text { (wood products carbon will decay } \\
\text { exponentially) }\end{array}$ & $\%$ & optional & optional \\
\hline & percFireFirstYear & $\begin{array}{l}\text { AGB percentage after timber } \\
\text { exploration which burns in the first } \\
\text { year (carbon released instantaneously). }\end{array}$ & $\%$ & optional & optional \\
\hline & percSlash & $\begin{array}{l}\text { AGB percentage after timber exploration } \\
\text { left in the ground as slash (carbon will } \\
\text { decay exponentially). }\end{array}$ & $\%$ & optional & optional \\
\hline & percElementalCarbon & $\begin{array}{l}\text { AGB percentage left in the ground as } \\
\text { slash (carbon will decay very slowly). }\end{array}$ & $\%$ & optional & optional \\
\hline & slashFireCycle & $\begin{array}{l}\text { Number of years to reburn slash left } \\
\text { in the ground from deforestation. }\end{array}$ & yrs (years) & optional & optional \\
\hline & decayRateWood & Wood products decay rate. & n.a. & no & no \\
\hline & decayRateSlash & Slash decay rate. & n.a. & no & no \\
\hline & decayRateElemCarbon & Elementar carbon decay rate. & n.a. & no & no \\
\hline & decayRateBGB & Roots decay rate. & n.a. & no & no \\
\hline \multirow[t]{5}{*}{$\begin{array}{l}\text { Secondary } \\
\text { Forest }\end{array}$} & agriculturalUseCycle & $\begin{array}{l}\text { Number of years it takes for agricultural } \\
\text { land to be abandoned or rest after } \\
\text { deforestation. }\end{array}$ & yrs & optional & optional \\
\hline & percRegrow & $\begin{array}{l}\text { Percentage of a given deforested area } \\
\text { which will become secondary forest. }\end{array}$ & $\%$ & optional & optional \\
\hline & initialAbandonmentCycle & $\begin{array}{l}\text { Number of years of abandonment, before } \\
\text { the secondaty vegetation can be identified } \\
\text { by Remote Sensing images. }\end{array}$ & yrs & optional & optional \\
\hline & halfLife & $\begin{array}{l}\text { Number of years it takes to } 50 \% \text { of the } \\
\text { secondary vegetation to be cut (after } \\
\text { identification in Remote Sensing images), } \\
\text { following an exponential curve } \\
\text { (representing permanence time). }\end{array}$ & yrs & optional & optional \\
\hline & modelRegrow & $\begin{array}{l}\text { Biophisical model of vegetation regeneration } \\
\text { adopted for a given region. }\end{array}$ & Model code & optional & no \\
\hline
\end{tabular}

area. The parameter percWood partially captures the effect of selective logging, but this parameter is restricted to explored forest areas that ended up being converted to clear-cut deforestation. We developed the INPE-EM framework using the TerraME modeling environment (Carneiro, 2006). We adopted a flexible and open-source architecture to allow not only the easy creation of application models, but also the modification of process representation in each model component if necessary.

\section{INPE-EM for the Brazilian Amazon}

Study area and scales. The goal of this study is to use the INPE-EM to estimate the carbon balance related to tropical 
Table 2 The INPE-EM parameters for Brazilian Amazonia: alternative sets of parameters for each submodel

\begin{tabular}{|c|c|c|c|c|c|}
\hline Biomass & B1 (baseline) & B2 & B3 & B4 & \\
\hline \multirow[t]{2}{*}{$A G B^{*}$} & Saatchi et al. (2007) & $\begin{array}{l}\text { Nogueira et al. } \\
\text { (2008) }\end{array}$ & MCT (2010) & Saatchi et al. (2011) & \\
\hline & $\begin{array}{l}\text { Space-variant: } \\
\text { 100-370 Mg ha } \\
\text { (non-spatial mode: }^{-1} \\
196 \mathrm{Mg} \mathrm{ha}^{-1} \text { ) }\end{array}$ & $\begin{array}{l}\text { Space-variant: } \\
\text { 100-320 Mg ha } \\
\text { (non-spatial mode: } \\
266 \mathrm{Mg} \mathrm{ha}^{-1} \text { ) }\end{array}$ & $\begin{array}{l}\text { Space-variant: } \\
\text { 100-418 Mg ha } \\
\text { (non-spatial mode: }^{-1} \\
197 \mathrm{Mg} \mathrm{ha}^{-1} \text { ) }\end{array}$ & $\begin{array}{l}\text { Space-variant: } \\
\text { 100-347 } \mathrm{Mg} \mathrm{ha}^{-1} \\
\text { (non-spatial mode: } \\
193 \mathrm{Mg} \mathrm{ha}^{-1} \text { ) }\end{array}$ & \\
\hline$B G B P \operatorname{erc} A G B^{*}$ & $30 \%$ & $20 \%$ & $28 \%$ & $30 \%$ & \\
\hline carbonPercBiomass & $48 \%$ & $48 \%$ & $48 \%$ & $48 \%$ & \\
\hline Primary forest & PF1 (baseline) & PF2 & PF3 & PF4 & PF5 \\
\hline percWood & $15 \%$ & $15 \%$ & $15 \%$ & $15 \%$ & $15 \%$ \\
\hline percFireFirstYear* & $50 \%$ & $30 \%$ & $70 \%$ & $90 \%$ & $\begin{array}{l}\text { Space-variant: } \\
30-70 \% \\
\text { (non-spatial } \\
\text { mode: } 50 \% \text { ) }\end{array}$ \\
\hline percSlash* & $48 \%$ & $68 \%$ & $28 \%$ & $8 \%$ & $\begin{array}{l}\text { Space-variant: } \\
70-30 \% \\
\text { (non-spatial } \\
\text { mode: } 48 \% \text { ) }\end{array}$ \\
\hline percElementarCarbon & $2 \%$ & $2 \%$ & $2 \%$ & $2 \%$ & $2 \%$ \\
\hline slashFireCycle & 3 years & 3 years & 3 years & 3 years & 3 years \\
\hline decayRateWood & 0.1 & 0.1 & 0.1 & 0.1 & 0.1 \\
\hline decayRateSlash & 0.4 & 0.4 & 0.4 & 0.4 & 0.4 \\
\hline decayRateElemCarbon & 0.001 & 0.001 & 0.001 & 0.001 & 0.001 \\
\hline decayRateBGB & 0.7 & 0.7 & 0.7 & 0.7 & 0.7 \\
\hline Secondary forest & SF1 (baseline) & SF2 & SF3 & SF4 & \\
\hline agriculturalUseCycle & 2 years & 2 years & 2 years & 2 years & \\
\hline abandonmentCycle & 3 years & 3 years & 3 years & 3 years & \\
\hline percRegrow* & $\begin{array}{l}\text { Space-variant: } \\
\text { 10-70\% (non-spatial } \\
\text { mode: } 19 \% \text { ) }\end{array}$ & $30 \%$ & $\begin{array}{l}\text { Space-variant: } \\
\text { 10-70\% (non-spatial } \\
\text { mode: } 19 \% \text { ) }\end{array}$ & $30 \%$ & \\
\hline halfLife* & $\begin{array}{l}\text { Space-variant: } \\
\text { 3-21 years } \\
\text { (non-spatial } \\
\text { mode: } 5 \text { years; } \\
\text { initial in 1960: } \\
21 \text { years) }\end{array}$ & $\begin{array}{l}\text { Space-variant: } \\
\text { 3-21 years } \\
\text { (non-spatial } \\
\text { mode: } 5 \text { years; } \\
\text { initial in 1960: } \\
21 \text { years) }\end{array}$ & 21 years & 21 years & \\
\hline modelRegrow & $\begin{array}{l}\text { Based on Houghton } \\
\text { et al. (2000) }\end{array}$ & $\begin{array}{l}\text { Based on Houghton } \\
\text { et al. (2000) }\end{array}$ & $\begin{array}{l}\text { Based on } \\
\text { Houghton et al. (2000) }\end{array}$ & $\begin{array}{l}\text { Based on Houghton } \\
\text { et al. (2000) }\end{array}$ & \\
\hline
\end{tabular}

*Parameters that vary across sub models.

rainforest deforestation in the Brazilian Amazon, an area of approximately $4000000 \mathrm{~km}^{2}$. Other types of native vegetation removal in the area (for instance, in savannas) are not considered. Brazil is politically divided into 26 federative states and a Federal District, and the Brazilian Amazon rainforest overlaps partially nine of these states. The spatial scale of this study divides the federative arrangement in the Brazilian Amazon into regular cells of $25 \times 25 \mathrm{~km}^{2}$, as Fig. 2 illustrates. The temporal scale incorporates the period from 1961 to 2009, in annual steps. During this time period, the use of INPE-EM in the spatial and/or non-spatial mode depends on the availability of spatially explicit deforestation maps, as discussed below.

Deforestation and biomass data sources. We use the PRODES Monitoring System, developed by the Brazilian National Space Institute (INPE), as the source of annual deforestation data (INPE, 2011a,b,c). The system estimates the annual deforestation rates $\left(\mathrm{km}^{2} \mathrm{yr}^{-1}\right)$ since 1988 using remote sensing imagery. Since 2000, PRODES has provided, in addition to the annual deforestation rate estimate, detailed spatial information (60 $\mathrm{m}$ resolution) about the new deforested 


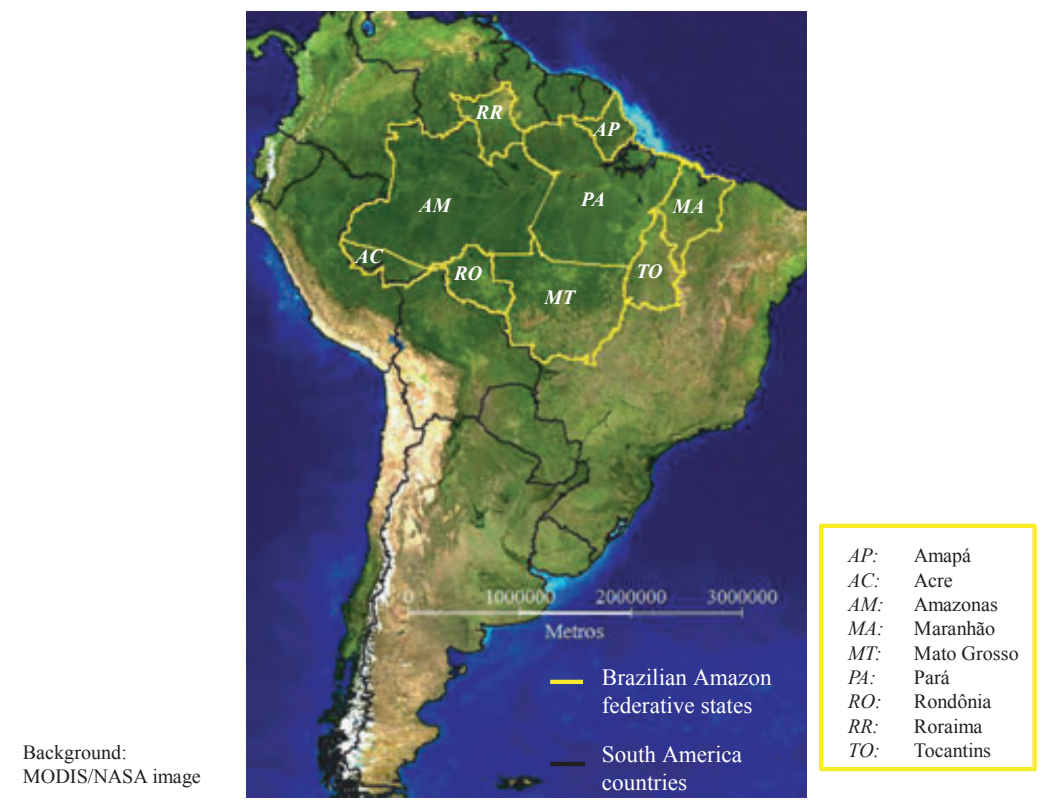

Fig. 2 Study area - The Brazilian Amazon: Cellular space and federative states.

areas identified in the satellite images each year. PRODES is recognized by the international community as a reliable source of deforestation information, being used as a reference to validate global assessments (Achard et al., 2002, 2004, 2007; DeFries et al., 2002; Hansen et al., 2008b) and several other regional studies (Morton et al., 2006; Hansen et al., 2008a; Broich et al., 2009). Previous similar emission studies (Ramankutty et al., 2007; Loarie et al., 2009) also used PRODES as a deforestation data source. Figure $3 a$ and $b$ present the total deforested area up to 1997 and 2009, respectively, according to the PRODES system (INPE, 2011a,b,c). Figure 3 illustrates how the deforestation process is heterogeneously distributed throughout the region and presents a spatially dependent pattern that is concentrated around areas cleared in previous decades (Alves, 2002) that are more connected to the rest of the country (Alves, 2001; Aguiar et al., 2007). Figure $3 c$ and d present the spatial distribution of the annual change (deforestation rate) identified in 2004 and 2009, representing the basic information we use in INPE-EM (see File S1).

With respect to the biomass information, there have been several efforts to produce maps of biomass distribution in the Brazilian Amazon using different resolution and data acquisition approaches (Houghton et al., 2001; Malhi et al., 2006; Nogueira et al., 2007; Fearnside et al., 2008). In this study, we choose four alternative maps: (B1) Saatch et al. (2007), (B2) Nogueira et al. (2008), (B3) MCT (2010) and (B4) Saatchi et al. $(2011 a, b)$. Please, refer the File S1 for further details about the biomass data sources. As Fig. 4 illustrates, biomass is heterogeneously distributed in the region. Besides, existing estimates present a wide variation in spatial distribution and magnitude.

Combining these data sources, we apply the INPE-EM for the Brazilian Amazon using the non-spatial mode for the period 1961-2001 and the spatial mode for 2002-2009. The
INPE/PRODES system reports annual rates after 1989 and an average decadal rate from 1979 to $1988\left(21000 \mathrm{~km}^{2} \mathrm{yr}^{-1}\right)$. INPE also estimated that the total extension of deforested area was $77172 \mathrm{~km}^{2}$ in 1978 and $28595 \mathrm{~km}^{2}$ in 1975 (Tardin et al., 1980). To fill the gap from 1961 to 1975 and from 1975 to 1978 , we adjusted an exponential curve to these values, representing a gradual increase. Houghton et al. adopted a constant $4000 \mathrm{~km}^{2}$ rate from 1960 to 1978, and INPE's average rate from 1979 to 1989 . Ramankutty et al. (2007) adopted a linear increase for the intervals 1960-1975-1989. Like Houghton et al. (2000), we chose to maintain the official INPE's average rate from 1979 to 1989 , but decided to adjust an exponential curve to the 1960-1975-1978 values, representing a gradual increase. Prior to 1961 , we considered that deforestation was negligible. From 2002 to 2009, we use the INPE-EM spatial mode. Each $25 \times 25 \mathrm{~km}^{2}$ cell has an estimate amount of cleared area (deforest) in each year from 2002 to 2009 (see File S1).

Concerning the biomass, we preprocessed all the data sources to remove low values corresponding to non-forest vegetation aboveground biomass $(A G B)$. In the spatial mode (2002-2009), our model considers the average $A G B$ value in each $25 \times 25 \mathrm{~km}^{2}$ cell excluding values smaller than $100 \mathrm{Mg} \mathrm{ha}^{-1}$. For the non-spatial mode (1961-2001), we adopt a constant $A G B$ value estimated as the average forest biomass $\left(>100 \mathrm{Mg} \mathrm{ha}^{-1}\right)$ of deforested cells in 2002. As Fig. 4 illustrates, the four maps are quite distinct in terms of their magnitude and spatial distribution. These differences directly influence the average $A G B$ value computed for the non-spatial mode. Table 2 summarizes the biomass parameter values adopted for the Brazilian Amazon. With respect to belowground biomass (BGB), Nogueira et al. (2008) report spatially explicit information, which corresponds, on average, to $20 \%$ of the AGB $(B G B P \operatorname{erc} A G B=20 \%)$. MCT (2010) reports BGB as $28 \%$ of the AGB $(B G B P e r c A G B=28 \%)$. Saatch et al. $(2007)$ do 

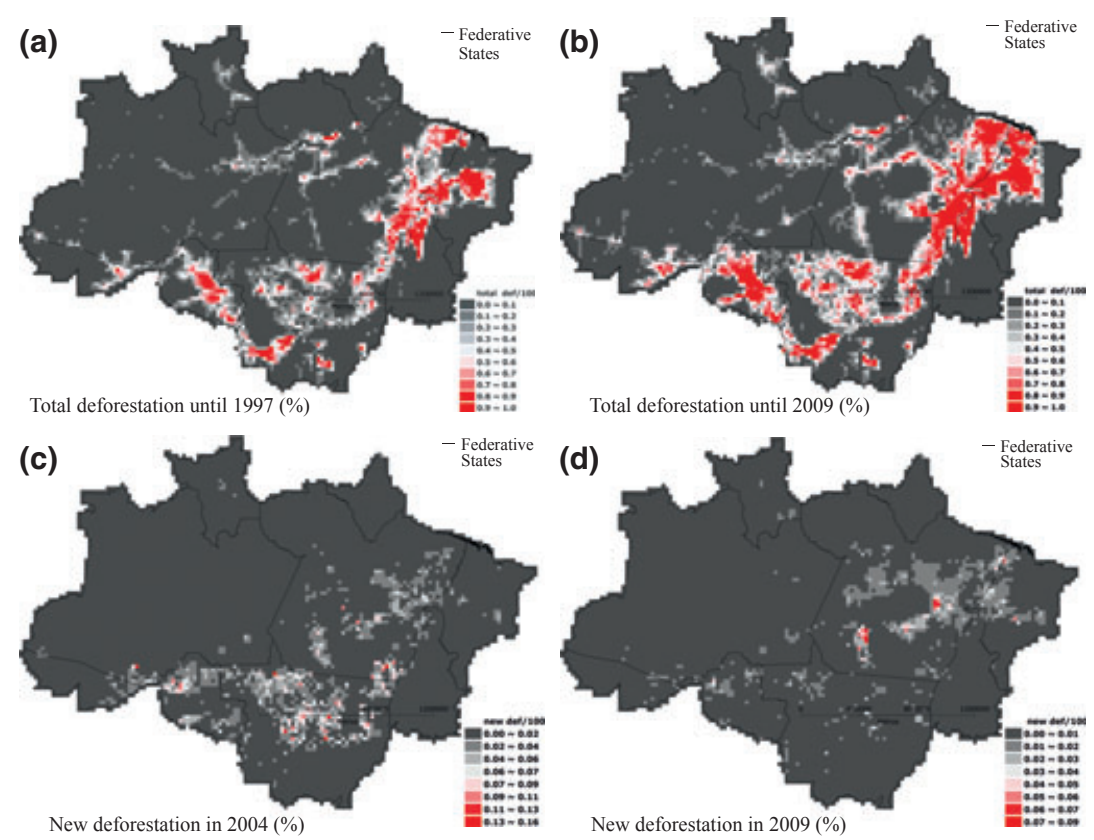

Fig. 3 The Brazilian Amazon deforestation represented in the cellular space $\left(25 \times 25 \mathrm{~km}^{2}\right)$ : (a) the total deforested area up to 1997; (b) the total deforested area up to 2009; (c) spatial rate distribution in 2004; (d) spatial rate distribution in 2009 (source: INPE, 2011a,b,c)
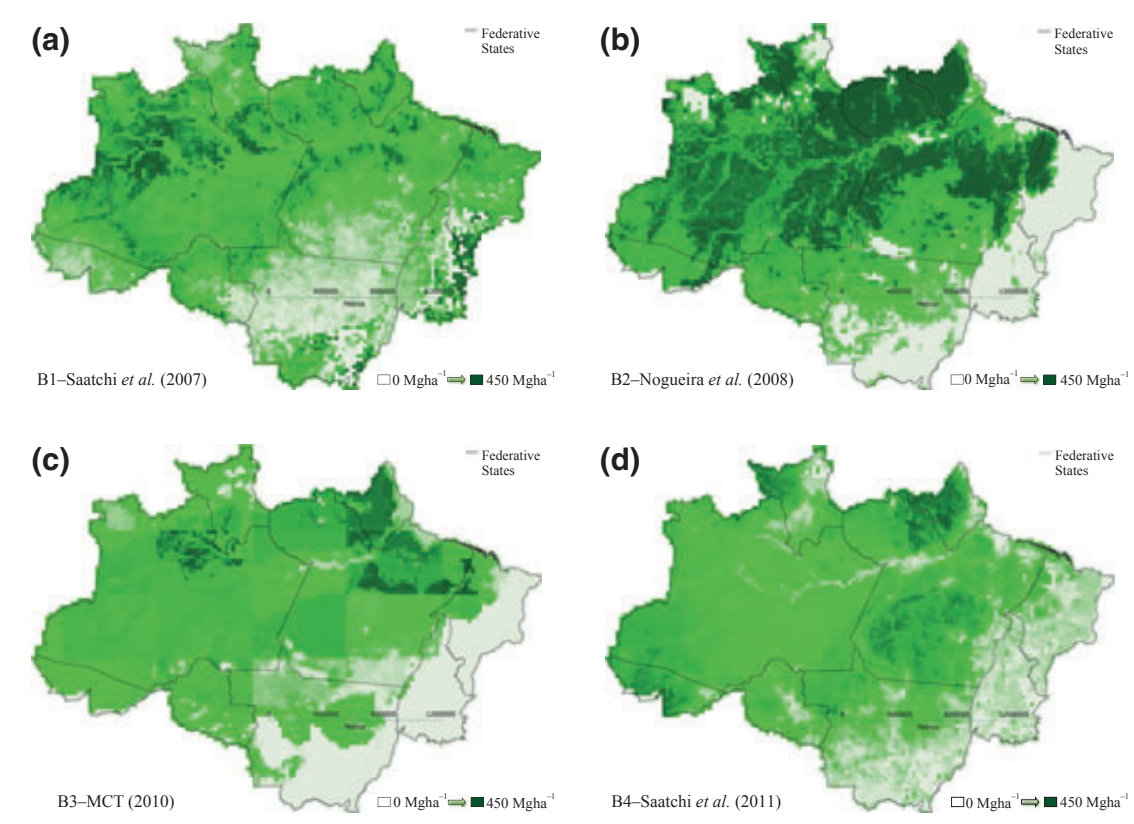

Fig. 4 The Brazilian Amazon forest biomass represented in the cellular space $\left(25 \times 25 \mathrm{~km}^{2}\right)$ : (a) B1 - Saatch et al. (2007); (b) B2 - Nogueira et al. (2008); (c) B3 - MCT (2010); (d) B4 - Saatchi et al. (2011a,b).

not report BGB, and we adopted a value of $30 \%$ (BGBPer$C A G B=30 \%)$. This is a mean value, based on dry land forest data from several studies (Fearnside et al., 2001; Keller et al., 2004; Luizão et al., 2004; Palace et al., 2007; da-Silva, 2007). Carbon content (carbonPercBiomass) is considered to be $48 \%$ of biomass (AGB and BGB).
Parameters for the representation of the deforestation process: primary forest parameters. To represent the primary forest process, we modified some of the parameters used by Houghton et al. (2000) based on more recent literature. The model represents the fate of the carbon in the removed biomass by timber extraction and slash-and-burn deforestation in each cell for 
each year. Therefore, we must define the percentage of biomass that is (1) removed as wood prior to clear-cut deforestation (percWood), (2) burnt and released in the first year (percFireFirstYear), (3) left on the ground to decompose (percSlash), and (4) converted to elemental carbon (percElementalCarbon).

The amount of wood removed by the forestry sector (percWood) in deforested areas is a large source of uncertainty in the model. The wood sector is very important to the regional economy of Amazonia. According to official information about the forestry sector in Amazonia (MMA, 2011), the total volume of timber consumed was 14.1 million $\mathrm{m}^{3}$ in 2009 and 24.5 million $\mathrm{m}^{3}$ in 2004 . In 2009, 65\% of this total volume came from Sustainable Forest Management Plans, 17\% from Legal Deforestation Licenses, and 18\% from unidentified sources. Even though deforestation licenses are a significant source of timber for the forestry sector in Brazil, a substantial portion still comes from unauthorized irregular deforestation and selective or cryptic logging. According to Asner et al. (2006), selective logging in the Brazilian Amazon leads to clear-cut deforestation of $32 \%$ of the areas within the next 4 years. Previous works have considered that emissions derived from cryptic logging in Amazonia would add 7\% to clear-cut deforestation emissions (Nepstad et al., 1999; DeFries et al., 2002; Loarie et al., 2009). The current version of INPE-EM does not calculate overall logging emissions for Amazonia, but it is necessary to determine the percentage of original biomass in deforested areas that was removed by the forestry sector legally or illegally, including by previous cryptic logging. Houghton et al. (2000) and Ramankutty et al. (2007) adopted $8 \%$ as the portion of the original biomass transferred to wood products during deforestation. However, given the magnitude of the forestry sector in Amazonia that is involved in both legal and illegal logging extraction processes, this value may be an underestimate. Thus, we adopted $15 \%$ as a mean value for percWood in all of our models, acknowledging that a more accurate estimate remains an open scientific question. Another source of uncertainty is the fate of the removed wood (whether in civil construction, charcoal, furniture, objects, wasted in the manufacturing process, other purposes). This uncertainty influences estimates of the number of years over which this share of the carbon will be released. As in Houghton et al. (2000), we consider an exponential decay rate of 0.1 per year for the wood products.

The most uncertain parameter, however, is the amount of remaining biomass after timber exploration, which is burnt in the first year (percFireFirstYear) and, consequently, how much is left on the ground (slash) to decompose biologically (percSlash). These parameters are crucial for annual emissions estimates because they modify the rate of emissions (Ramankutty et al., 2007). Two aspects influence the parameter percFireFirstYear: fire efficiency (associated with forest structure, species distribution, previous natural disturbance, and weather conditions) and the available capital and dominant land-use system. Houghton et al. (2000) and Ramankutty et al. (2007) assumed that only $20 \%$ of the original biomass would burn and release carbon in the same year in which deforestation is detected. However, considering recent studies of fire efficiency (Carvalho et al., 2001), agrarian heterogeneity (Walker et al., 2000; Aguiar et al., 2007; Costa, 2008) and agricultural evolution in the region (Morton et al., 2006; Martinelli et al., 2010; Espindola et al., 2011), we assume in our baseline Primary forest
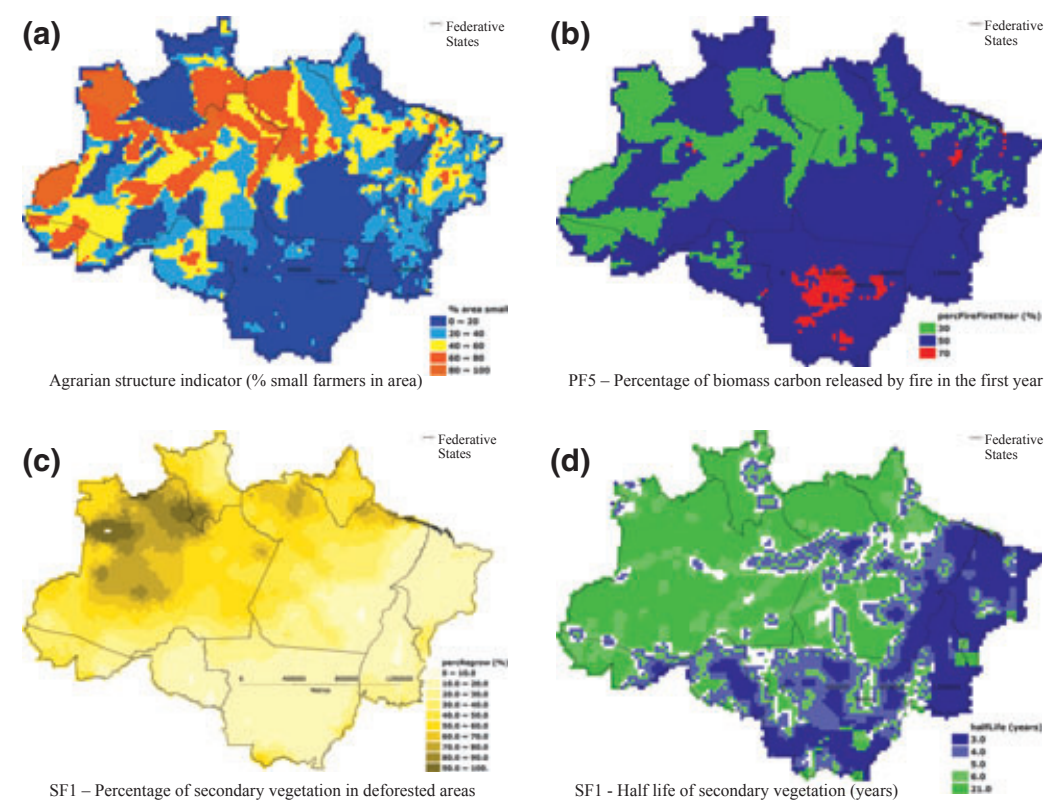

Fig. 5 The Amazonia intra-regional heterogeneity and sub-model spatial distribution parameters: (a) agrarian structure indicator: the percentage of small farms in relation to the municipality area; (b) the percentage of biomass released in the clear-cut year by fire according to sub-model PF5 (source: Aguiar et al., 2007; Espindola et al., 2011); (c) the percentage of secondary vegetation in relation to deforested areas according to sub-model SF1 (source: Almeida et al., (2009)); (d) the half-life of secondary vegetation according to sub-model SF1 (source: Almeida et al., 2009). 
model (PF1) that, on average, $50 \%$ of the biomass (remaining after timber exploitation) will burn in the first year (percFireFirstYear $=50 \%$ ). We consider that the region today is composed of heterogeneous actors that are able to clear the land with different technologies and speeds. In the PF1 model, we adopted an average value for the entire area because we did not have a solid basis from the literature for its spatial distribution in relation to the heterogeneity of actors and land-use trajectories across the region. To investigate the sensitivity of the model to the observed range and intra-regional heterogeneity of the percFireFirstYear parameter, we consider three alternative model configurations using 30\% (PF2), 70\% (PF3), and $90 \%$ (PF4) as average values, repeated for every cell. We also define a spatially explicit model (PF5) in which this parameter varies in each cell according to the dominant land use after deforestation and agrarian structure indicators derived from an agricultural census (IBGE, 2006; Aguiar et al., 2007; Espindola et al., 2011). Figure 5b presents the spatial distribution of this parameter in the PF5 model. This exploratory PF5 model is based on our field knowledge that highly capitalized actors in mechanized agricultural areas are able to clear the land in 1 or 2 years; thus, in areas where large farms are predominant, percFireFirstYear is higher than in areas of traditional small-scale agriculture.

Other primary forest process parameters are defined as follows. A fixed proportion of $2 \%$ of the remaining biomass after timber exploration is transformed into elemental carbon (percElementalCarbon) in all submodels (Houghton et al., 2000). The percentage of slash (percSlash) is adjusted as $100 \%$ - (percFireFirstYear) - (percElementalCarbon) for each cell. The decay rates for components (c) and (d) are based on Houghton et al. (2000). All submodels assume that the estimated BGB will release carbon through biological decomposition at a 0.7 per year exponential decay rate (decayRateBGB), based on Silver et al. (2005). Table 2 summarizes the alternative primary forest model parameters.

Parameters for the representation of the deforestation process: secondary forest parameters. The INPE-EM model represents the secondary forest emission/absorption process based on three groups of parameters, as detailed in Section 4.1 (Table 1): the percentage of deforested area in which secondary vegetation grows (percRegrow) after some years of agricultural use (agriculturalUseCycle); the secondary vegetation growth curve (modelRegrow); and the secondary vegetation removal time lag (halfLife) after some years of abandonment (initialAbandonmentCycle). For the parameter modelRegrow, we use the same vegetation growth curve proposed by Houghton et al. (2000) and Ramankutty et al. (2007), in which forests recover $70 \%$ of their original biomass in 25 years and the remaining $30 \%$ over the next 50 years.

For parameter percRegrow, Houghton et al. (2000) adopted average values for each state, ranging from 5\% in Goiás to $65 \%$ in Maranhão, based on a land cover classification derived from Landsat images in 1986. We refined the process representation of this parameter using spatially distributed variables derived from Almeida (2009) and Almeida et al. (2009) as follows. In these studies, the area occupied by secondary vegeta- tion in the Brazilian Amazon for 2006 is estimated with a sampling scheme in which 26 Landsat TM images distributed into seven strata were selected according to their degree of deforestation. In these 26 scenes, secondary vegetation areas were mapped and validated in the field. A regression model was constructed to estimate the area covered by secondary vegetation in the remaining images. The percentage of deforested area (according to PRODES data) covered by secondary vegetation in 2006 is the dependent variable in their regression model. For the whole of Amazonia, they estimated that $19.38 \pm 1.83 \%$ of secondary vegetation in deforested areas in 2006. Uncertainty was estimated using a Monte Carlo simulation. The recently launched TerraClass land-use monitoring system (INPE, 2011c) reported $21 \%$ of secondary vegetation in deforested areas in 2008, confirming the estimates of Almeida (2009). Figure $5 \mathrm{~b}$ presents the distribution of the variable percentage of secondary vegetation in previously deforested areas, derived using the regression equation. We use the spatial distribution of these values as parameter percRegrow in our baseline SF1 submodel.

The distribution of this variable (the percentage of secondary vegetation in previously deforested areas) represents regional heterogeneity reflected by the selection of independent variables in the regression analysis that were selected on the basis of the literature: deforestation area, hydrographic area, agrarian structure indicator, and the area of conservation units in each scene. The authors estimated an uncertainty in the regression model of approximately $1 \%$ for the 26 sample images and $18 \%$ to the other images. Even with this level of uncertainty, we consider this approach a better representation than for instance state level averages used in previous works (Houghton et al., 2000), which would hide large intraregional internal differences. The regression model coefficients confirm previous studies (Alves et al., 2003; Perz \& Skole, 2003; Mello et al., 2011) relating the distribution of secondary vegetation in the Brazilian Amazon to the presence of small farmers (according to the distance to rivers and indicators of agrarian structure) and the degree of land availability and occupation of a given area (deforested and conservation units per area, independent variables).

Finally, it is necessary to define the permanence time of the secondary vegetation so that the model can estimate how much of the carbon captured during re-growth will be released in a given year, represented by the parameters halfLife and initialAbandonmentCycle. We also used the results of Almeida (2009) as a basis for these parameters in our baseline SF1 model. These authors estimated the spatial distribution of the secondary vegetation half-life according to the secondary vegetation mapped in 1997 and removed in subsequent years of mapping. The half-life was computed using exponential decay equations adjusted using 2000, 2003 and 2006 classified images and based on the same seven strata according to the degree of deforestation. For areas with deforestation below 30\%, the half-life lies between 4 and 7 years. For areas with greater than $30 \%$ deforestation, the half-life is $3-4$ years. Therefore, we computed the degree of deforestation in each cell in 2006 and then distributed the half-life values according to the findings of Almeida (2009) (Fig. 5b and d). 
Table 3 A summary of the explorations for the Brazilian Amazon: biomass, primary, and secondary forest submodel combination

\begin{tabular}{|c|c|c|c|c|c|}
\hline Exploration & $\begin{array}{l}\text { Primary forest } \\
\text { submodel }\end{array}$ & Secondary forest submodel & $\begin{array}{l}\text { Biomass } \\
\text { submodel }\end{array}$ & $\begin{array}{l}\text { Regional } \\
\text { analysis }\end{array}$ & State level analysis \\
\hline 1 & PF1 & Not considered & $\mathrm{B} 1, \mathrm{~B} 2, \mathrm{~B} 3, \mathrm{~B} 4$ & yes & yes (MT, RO and PA) \\
\hline 2 & $\begin{array}{l}\text { PF1, PF2, PF3, } \\
\text { PF4, PF5 }\end{array}$ & Not considered & B1 & yes & yes (MT and $A M)$ \\
\hline 3 & PF1 & SF1 & $\mathrm{B} 1, \mathrm{~B} 2, \mathrm{~B} 3, \mathrm{~B} 4$ & yes & no \\
\hline 4 & PF1 & $\mathrm{SF} 1, \mathrm{SF} 2, \mathrm{SF} 3, \mathrm{SF} 4$ & B1 & yes & no \\
\hline
\end{tabular}

In addition to the baseline SF1 submodel, we also run three alternative secondary forest submodels (SF2, SF3 and SF4). The goal of these simulations is to explore how the percentage of secondary vegetation in deforested areas and the half-life affect the $\mathrm{CO}_{2}$ estimates. Submodel SF2 varies the percentage of secondary vegetation in each deforested cell. Using Almeida et al. (2009), the average percentage of secondary vegetation in the deforested areas is $19 \%$. Ramankutty et al. (2007), using a land-use transition matrix defined by Fearnside (1996), considered $32 \%$ of the deforested land is in regrowing vegetation. Thus, the SF2 submodel adopts $30 \%$ as a unique value in all the cells. The SF3 submodel increases the half-life parameter to 21 years, which is the maximum value in Almeida (2009). SF4 changes both parameters at the same time.

Table 2 summarizes the individual biomass, primary, and secondary forest parameters for the Brazilian Amazon. The next section describes how we combine the four alternative biomass maps with primary and secondary forest submodels to explore different model uncertainties.

Explorations: protocols of the submodel combination. There are many possible combinations of Table 2 biomass, primary, and secondary forest submodels. To explore different model uncertainties in the results section, we selected some key combinations (named Explorations), summarized in Table 3.

We first explore the primary forest submodel results without considering the secondary forest in the estimates. Exploration 1 compares the estimates obtained by the baseline PF1 submodel when using four different biomass data sources (submodels B1 to B4). Then, to explore model uncertainties other than the biomass, Exploration 2 compares alternative primary forest submodels (PF2 to PF5) with the baseline PF1 submodel using just one of the biomass maps represented by submodel B1 (Saatch et al., 2007). We choose Saatch et al. (2007) as a baseline for the explorations because it has been used in recent similar spatially explicit models (Loarie et al., 2009). Submodels PF1 to PF5 vary in relation to the most uncertain parameters in that the component: the amount of remaining biomass that is burnt in the year of clear-cut deforestation (percFireFirstYear) and the amount left in the ground to decompose (percSlash), as Table 2 illustrates.

The influence of the secondary forest process on the emission estimates is also explored in two steps. Exploration 3 compares the $\mathrm{CO}_{2}$ balance using the four alternative biomass maps using the baseline PF1 and SF1 submodels. Then, in Exploration 4, we compare alternative submodels (SF2, SF3 and SF4) representing the secondary vegetation dynamics, also using biomass B1 as an example (Saatch et al., 2007). Compared with SF1, model SF2 varies the percRegrow parameter, SF3 varies the halfLife parameter, and SF4 varies both of these parameters (see Table 2).

All explorations estimate emissions for the whole of the Brazilian Amazon. To illustrate the impacts of the intra-regional heterogeneity on the model results, Explorations 1 and 2 also compare some results at the sub-regional level for selected federative states with distinct socioeconomic and biophysical characteristics. Exploration 1 compares the primary forest (a) Brazilian Amazon: instantaneous, non-process $\mathrm{CO}_{2}$ emission

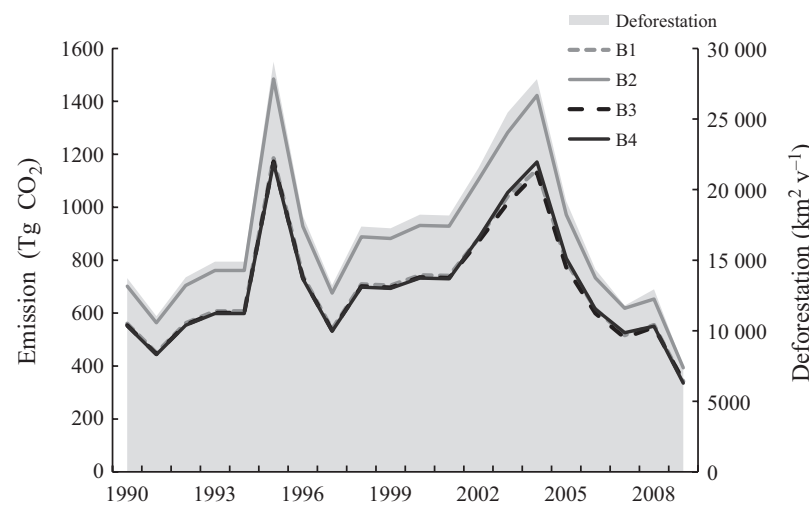

(b) Brazilian Amazon: process-based $\mathrm{CO}_{2}$ Emission (PF1)

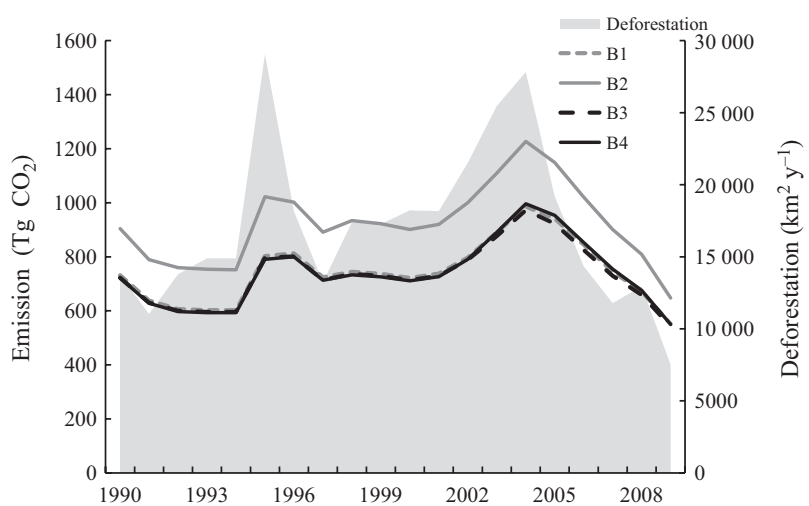

Fig. 6 Results: $\mathrm{CO}_{2}$ emissions from primary forest deforestation comparing four biomass data sources (Model P1S1) at the Brazilian Amazon level: (a) instantaneous (non-process) and (b) process-based. 
emission estimates using alternative biomass maps for the three states with higher historical deforestation rates: Mato Grosso, Pará and Rondônia. Exploration 2 illustrates the potential effects of using a spatially explicit variable to represent the parameter percFirefirstYear (model SF5) by comparing two states with distinct agrarian structures: Mato Grosso and Amazonas (Fig. 5).

\section{Results}

According to the protocol discussed in the previous section, Section 5.1 presents the emission model results for the primary forest deforestation process (Explorations 1 and 2). Section 5.2 includes the Secondary Forest (SF) dynamics and explores the $\mathrm{CO}_{2}$ balance estimates (Explorations 4 and 5).

\section{Primary forest results}

Figure 6 presents the estimate of $\mathrm{CO}_{2}$ emissions related to primary forest deforestation for the whole of the Brazilian Amazon from 1990 to 2009 using four different biomass maps (Exploration 1). For comparison, Figure 6a illustrates the results of a non-process estimate, equivalent to the instantaneous emissions of $100 \%$ of the carbon. Figure $6 \mathrm{~b}$ presents the estimates using the baseline PF1 model (Table 2), in which $50 \%$ of AGB carbon (after 15\% of timber extraction) is released in the first year by fire. Table 4 summarizes the estimates for the different time periods, in $\mathrm{TgCO}_{2} \mathrm{yr}^{-1}$ and $\mathrm{PgCyr}^{-1}$, using a $3.67 \mathrm{C}-\mathrm{CO}_{2}$ conversion factor.

As Fig. 6 and Table 4 show, emissions estimates based on biomass submodel B2 (Nogueira et al., 2008) are considerably higher than the estimates based on other biomass submodels. For example, for the 20002009 decade, the values for B2 process-based emissions are $968 \mathrm{Tg} \mathrm{CO}_{2} \mathrm{yr}^{-1}\left(0.26 \mathrm{Pg} \mathrm{C} \mathrm{yr}^{-1}\right)$. The average of estimated emissions based on B1, B3 and B4 submodels in the same period is $785 \mathrm{Tg} \mathrm{CO}_{2} \mathrm{yr}^{-1}\left(0.21 \mathrm{Pg} \mathrm{C} \mathrm{yr}^{-1}\right)$. The results from $\mathrm{B} 1, \mathrm{~B} 3$, and $\mathrm{B} 4$ are quite similar when considering the entire extent of the Brazilian Amazon in spite of the visual differences among the biomass maps (Fig. 4). However, when performing more detailed analyses, for instance at the state level, the heterogeneous spatial distribution of the biomass values also influence the model results based on B1, B3 and B4 submodels. As an example, we compare the emission estimates for Mato Grosso, Pará and Rondônia (Fig. 7a-c, respectively).

As Fig. 7 illustrates, submodel B4 leads to higher estimates than those of B1 and B3 in Mato Grosso. In Rondônia, for instance, B4 leads to smaller numbers, whereas in Pará, the results are more similar to those obtained at the regional level (Fig. 6b). In spite of this, in Pará, emissions using B1 are smaller than the ones obtained using B3 and B4. Such differences resulting from the biomass data sources bring a significant component of uncertainty to deforestation emission estimates. In addition to the differences among data sources discussed above, there are reported uncertainties in each of the biomass sources. For instance, Saatchi et al. $(2011 \mathrm{a}, \mathrm{b})$ report a spatially explicit error in the AGB biomass. On the basis of the reported error, we estimated range emissions for each cell. The results demonstrate a variation of 15-19\% compared with the estimate shown in $6 \mathrm{~b}$ for Saatchi et al. (2011a,b), depending on the year. In summary, there are two sources of uncertainty in the emissions estimates related to the biomass maps: (1) The variation of the magnitude and spatial distribution among data sources (above- and belowground). This variation can result in a $20-25 \%$ increase or decrease in estimates for the entire region, as well as causing intraregional relative differences. (2) The intrinsic error associated with the methodology used to generate the biomass maps can be as high as $15 \%$.

Another important aspect of the biomass spatial distribution and heterogeneity is the direction of the new deforestation frontiers. In spite of the differences in biomass data sources discussed above, an analysis of the spatial distribution of deforestation spatial patterns from 2002 to 2009 indicates that the deforestation frontier is moving to areas of higher biomass. Table 4 summarizes these results. This increase in biomass values as was also previously pointed out by Loarie et al. (2009). As deforestation rates have decreased considerably since 2005, emission estimates have also decreased, in spite of the increase in biomass values per unit of area (ha).

The remainder of this section explores another important source of uncertainty in the Primary Forest deforestation process: the amount of remaining biomass (after wood removal as timber) that is burnt in the year of clear-cut deforestation (Exploration 2). Figure 8a compares the results of the baseline model PF1 (percFireFirstYear $=50 \%)$ with the alternative models PF2 (30\%), PF3 (70\%), and PF4 (90\%), and a single biomass data source (Saatch et al., 2007). Figure $8 \mathrm{~b}-\mathrm{d}$ represent the relative contributions of the different model components in the comparison of PF1, PF2, and PF3, respectively.

Figure 8 illustrates how this parameter controls the pace of carbon release. The larger the parameter, the faster carbon is emitted. For instance, in 2004, a peak deforestation rate year, PF1 submodel estimates $986 \mathrm{Tg}$ $\mathrm{CO}_{2} \mathrm{yr}^{-1}\left(0.27 \mathrm{Pg} \mathrm{C} \mathrm{yr}^{-1}\right)$. PF2 estimates a smaller value, $959 \mathrm{Tg} \mathrm{CO}_{2} \mathrm{yr}^{-1}\left(0.26 \mathrm{Pg} \mathrm{C} \mathrm{yr}^{-1}\right)$, as the carbon will be released along the following years. On the other 
A.P.D. AGUIAR et al.

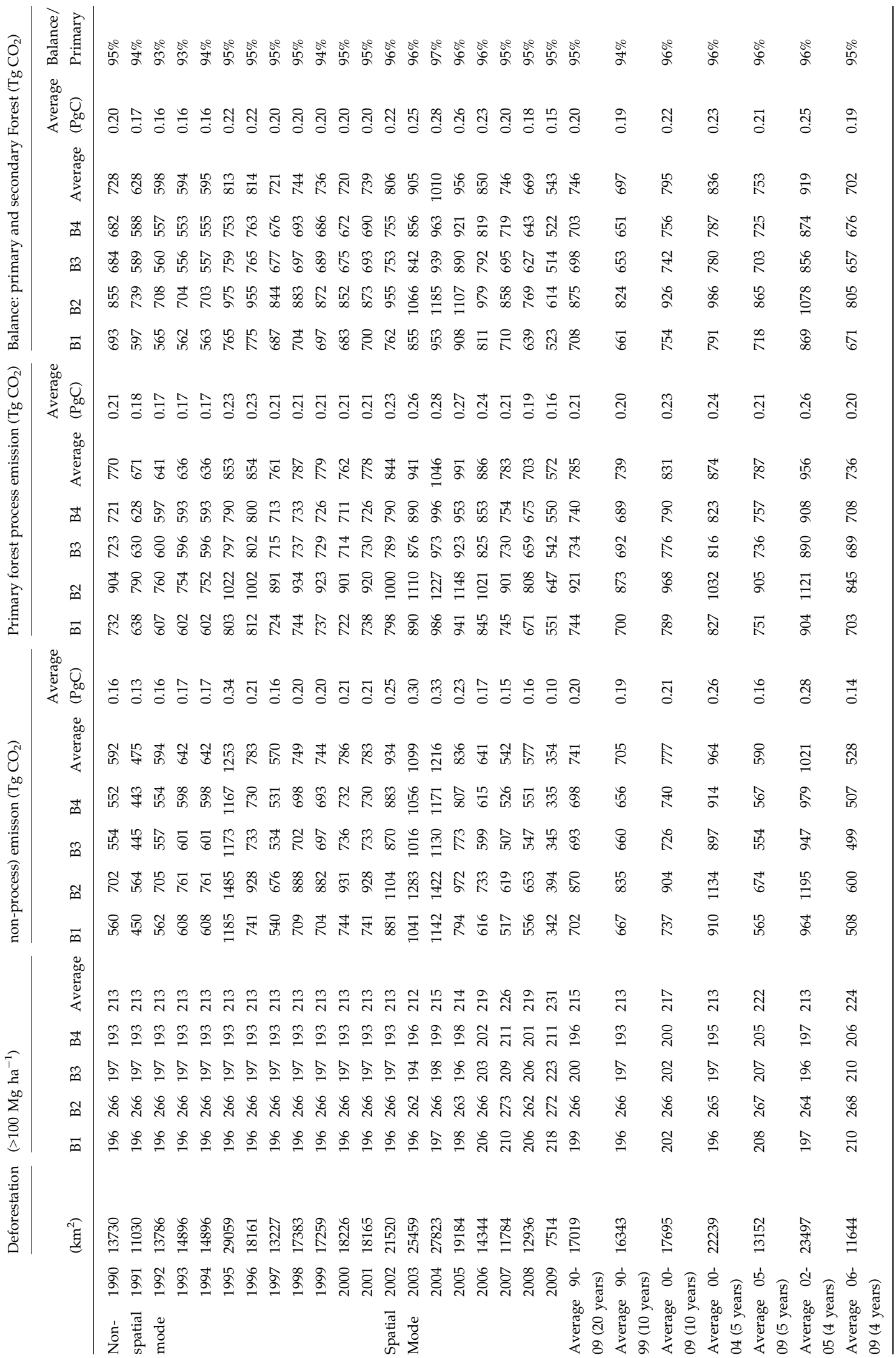



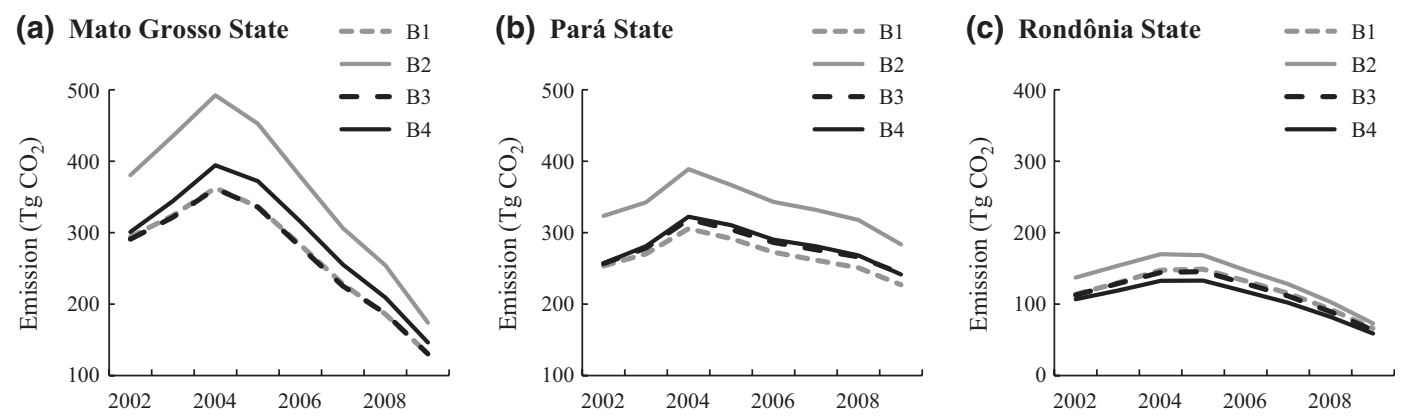

Fig. 7 Results: $\mathrm{CO}_{2}$ emissions from primary forest deforestation comparing four biomass sources (Model P1S1) at the state level in (a) Mato Grosso, (b) Pará, and (c) Rondônia using biomass data from Saatch et al. (2007).

(a) PF2 - 30\% Burnt first year

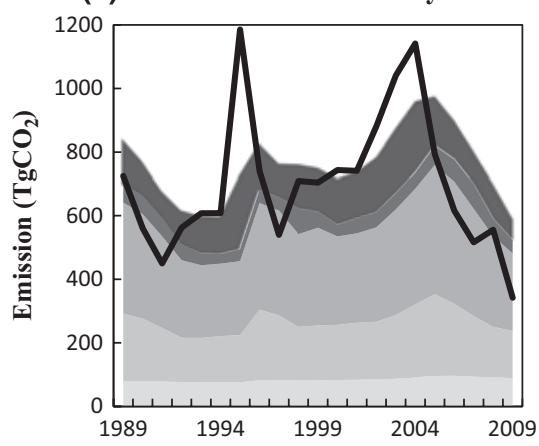

(c) PF3 - 70\% Burnt first year

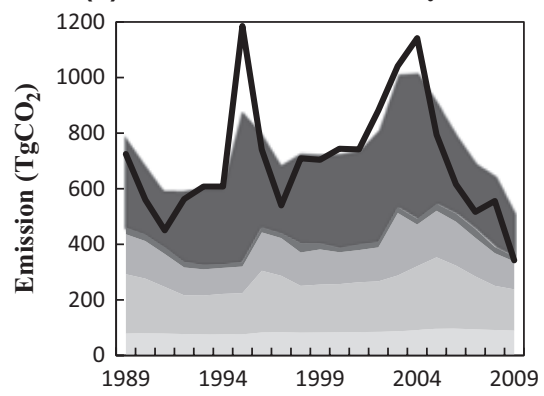

(b) PF1 - 50\% Burnt first year

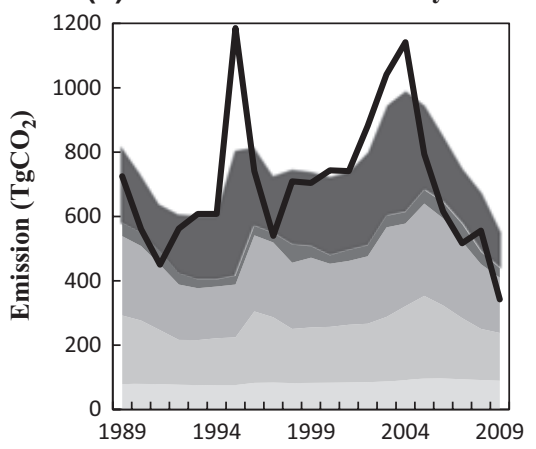

(d) PF4 - 90\% Burnt first year

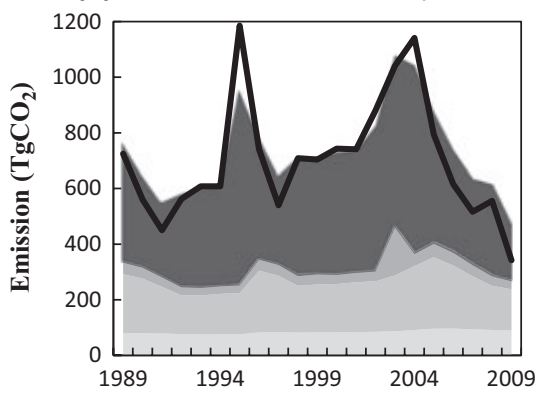

Fig. 8 Results: $\mathrm{CO}_{2}$ emissions from primary forest deforestation comparing alternative process parameters at the Brazilian Amazon level using biomass data from Saatch et al. (2007).

(a) Brazilian Amazon

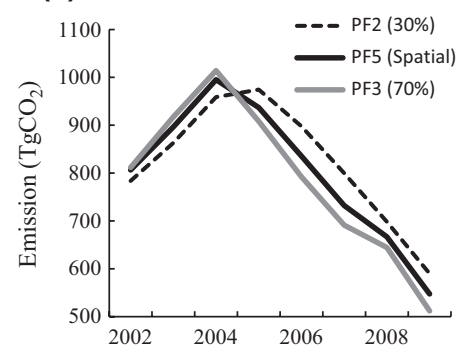

(b) Mato Grosso State

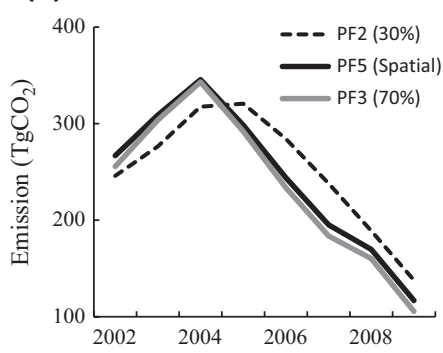

(c) Amazonas State

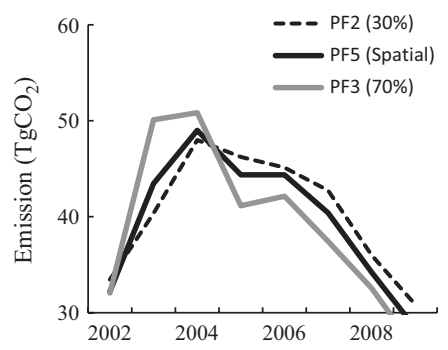

Fig. 9 Results: $\mathrm{CO}_{2}$ emissions from primary forest deforestation comparing spatial process parameters at the Brazilian Amazon level and at the state level (Mato Grosso and Amazonas examples), using biomass data from Saatch et al. (2007). 
hand, in 2009, when deforestation rate is lower, PF1 estimates $551 \mathrm{Tg} \mathrm{CO}_{2} \mathrm{yr}^{-1}\left(0.15 \mathrm{Pg} \mathrm{Cyr}^{-1}\right)$ and PF2 a larger value, $590 \mathrm{Tg} \mathrm{CO}_{2} \mathrm{yr}^{-1}\left(0.16 \mathrm{Pg} \mathrm{C} \mathrm{yr}^{-1}\right)$, because of the past years slash contribution. In the long term, the same amount of carbon will be emitted independent of this factor. In contrast, the differences in the biomass data sources discussed above actually control the overall amount of carbon released. However, the percentage of biomass burned in the first year is a crucial factor for accurate annual estimates. Figure 9 compares the results of applying the PF5 model, in which parameter percFireFirstYear is spatially explicit, to those of PF2 (percFireFirstYear $=30 \%$ ) and PF3 (percFireFirstYear $=70 \%$ ), considering different areas of analysis (the Brazilian Amazon, Mato Grosso and Amazonas) to explore the intra-regional variability.

Figure 9 shows that the PF5 estimates lie between PF2 and PF3 at the regional level; on average, parameter percFireFirstYear is close to $50 \%$. Nevertheless, the models' results differ in Mato Grosso State, where PF5 results are more similar to those of PF3 (70\%). In contrast, in Amazonas State, PF5 is closer to PF2 (30\%). This difference indicates the importance of refining this parameter for more local analyses, especially when detailed annual estimates are required.

\section{Carbon balance results}

Table 4 presents the $\mathrm{CO}_{2}$ balance for the entire extension of the Brazilian Amazon from 1990 to 2009 using the PF1SF1 model (Exploration 3). Our average balance estimates, considering all biomass data sources, are 697 (1990-1999) and $795 \mathrm{Tg} \mathrm{CO} 2 \mathrm{y}^{-1}$ (2000-2009), or 0.19 and $0.22 \mathrm{Pg} \mathrm{C} \mathrm{yr}^{-1}$, respectively. Compared with the primary forest process-based emission estimates, the re-growth of deforested vegetation does not contribute significantly to the emissions reduction (on average, 5\% in both periods of time, see Table 4). The short lifetime (5 years, on average) of the secondary vegetation in our baseline SF1 model (Almeida, 2009) explains this result.

In the remaining part of this section, we compare alternative secondary forest submodels. The goal is to explore how the percentage of secondary vegetation in deforested areas (percRegrow) and lifetime (halfLife) affect the $\mathrm{CO}_{2}$ estimates (Exploration 4). We fix the baseline primary forest (PF1) and biomass (B1) submodels, and perform three alternative secondary forest model simulations (SF2, SF3, and SF4). We vary one parameter at a time in SF2 and SF3 and both parameters in SF4 (Table 3). Figure 10 presents the results. (a) Secondary forest emission

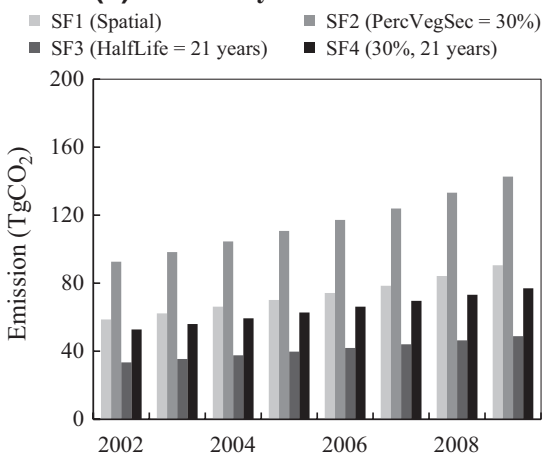

(b) Secondary forest absorption

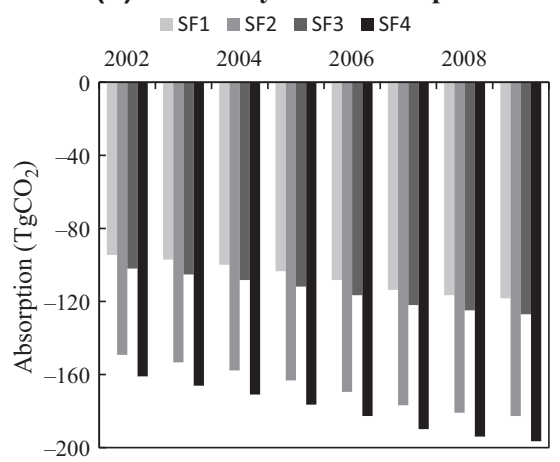

(c) Primary and Secondary Forest $\mathrm{CO}_{2}$ Balance

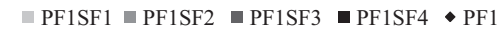

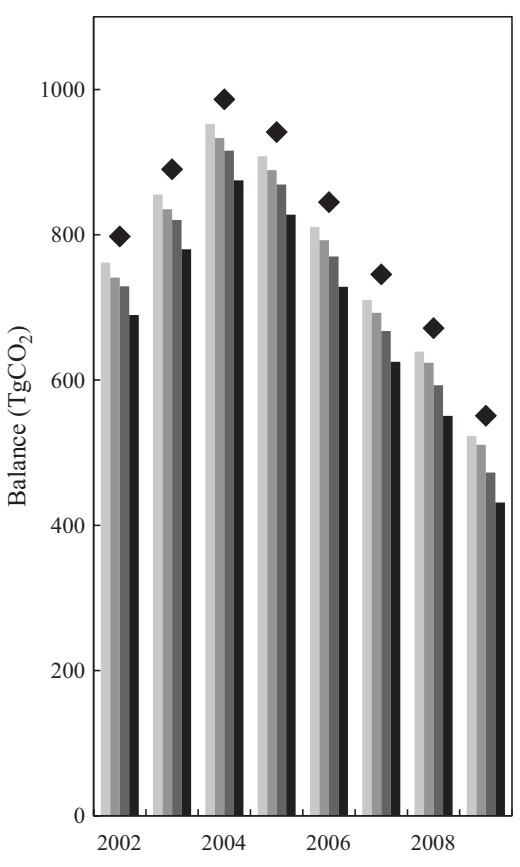

Fig. 10 Results: $\mathrm{CO}_{2}$ balance from comparisons of alternative process parameters (SF1, SF2, SF3, and SF4), using biomass data from Saatch et al. (2007): (a) secondary forest emissions; (b) secondary forest absorption; (c) balance, using primary forest model PF1. 
As Fig. 10 illustrates, SF2 submodel results produce higher emission and absorption values when compared to SF1. The comparatively higher percRegrow parameter (30\% in SF2 vs. $19 \%$, on average, in SF1) explains this result. The larger area of secondary vegetation increases $\mathrm{CO}_{2}$ absorption rates because more vegetation is growing. However, emission rates also increase because consequently a larger amount of secondary vegetation biomass will be removed some years later, according to the halfLife parameter. Thus, submodel SF2 results in a small increase in the difference between the balance and primary forest deforestation emissions (Fig. 10b and c). In comparison, increasing the halfLife parameter, as in model SF3 (21 years compared with 5 years, on average, in model SF1), contributes to a higher difference between balance and primary forest emissions (Fig. 10c). Finally, model SF4 explores changing both parameters. Balance estimates using PF1SF4 are considerably lower than the primary forest deforestation emissions (PF1), at $15 \%$, on average, for the time period 2000-2009. When using PF1SF1, this decrease is only $5 \%$.

This result is important for emission reduction policies: valuing the secondary vegetation, both by restoring previously deforested areas and creating incentives for a longer lifetime, would positively influence final balance results, reducing net $\mathrm{CO}_{2}$ emissions in the region. We further discuss this and other implications of our results in the next section.

\section{Discussion}

In the Brazilian Amazon, the largest source of uncertainty regarding carbon emissions from deforestation is the spatial distribution of biomass. Differences among emissions estimates based on different biomass data sources can be on the order of $20 \%$ using our baseline model parameters. Although estimates based on submodels B1 (Saatch et al., 2007), B3 (MCT, 2010) and B4 (Saatchi et al., 2011a,b) are relatively similar at the regional level, those based on B2 (Nogueira et al., 2008) are significantly higher. This difference could be even higher if we had adopted the same percentage of BGB in relation to AGB in all the submodels. Parameter $B G B-$ perc $A G B$ is $20 \%$ in B2, $28 \%$ in B3 and $30 \%$ in B1-B4. Thus, the emission estimate differences would increase to $30 \%$ as BGB contribution in B2 would be larger. In addition to magnitude differences, existing biomass maps have significant heterogeneous spatial distributions of high and low AGB values throughout the region (see Fig. 4). Therefore, when using the model to estimate emissions at the sub-regional or local level, estimates based on different maps will not necessarily follow the same relative order of magnitude. These results have a direct impact on the implementation and efficacy of emissions reduction mechanisms, such as REDD or REDD+. Although relative changes of emissions from deforestation and degradation may be less influenced by absolute value of biomass, the magnitude of emission and its geographic distribution depend significantly on the forest biomass and its uncertainty. Therefore, a key issue in the implementation of REDD+ is the reduction of uncertainty in the magnitude and the spatial distribution of forest biomass. In general, the methodology to improve the biomass estimation in Amazonia can be divided into two categories: (1) Development of a systematic forest inventory as in most national inventory systems in temperate countries such as the US Forest Service FIA (Forest Inventory and Analysis) (Heath et al., 2010). Given the vast region of Amazonia, inaccessibility of different regions, and the small-scale variations of forest structure and biomass compared to the even-aged temperate forests, the establishment of a systematic inventory system may not be feasible (Clark and Clark, 2000; Shugart et al., 2010). (2) The use of satellite remote sensing data sensitive to forest structure and biomass such as Lidar and Radar sensors calibrated with limited ground measurements (Dubayah et al., 2010; Shugart et al., 2010; Le Toan et al., 2011; Saatchi et al., 2011a,b). Although there are several ongoing projects to develop the spaceborne missions, currently, the most effective remote sensing techniques are airborne (Asner et al., 2010; Dubayah et al., 2010; Saatchi et al., 2011a,b). We consider an integrated approach using existing airborne and satellite observations and a reasonable network of the field inventory plots for calibration and upscaling of the biomass to landscape scale as the most cost-effective approach to provide spatially refined and temporally constraint estimates of forest biomass and changes in tropical forests (Saatchi et al., 2011a,b).

A large uncertainty in estimating tropical forest biomass over the landscape is also related to the scale of maps and the analysis. In this study, we used maps generated at different scales $(\sim 1-5 \mathrm{~km})$ that do not correspond to the scale of mapping deforestation (30 $100 \mathrm{~m}$ ), and the scale of the analysis $(25 \mathrm{~km})$. Forest biomass mapped at different spatial resolutions and using different approaches will aggregate to different values at larger scales (e.g. $25 \mathrm{~km}$ ). In general, biomass maps based on remote sensing approaches capture the heterogeneity in the forest cover, structure, and landscape variations (e.g. topography, soil). However, maps that are developed from interpolations of limited field data do not include the heterogeneity of the landscape and forest cover. In general field samples collected in a nonrandom or nonsystematic method represent forests with higher biomass, a phenomenon known as the majestic 
forest bias (Phillips et al. 2004). In this study, maps based on derived field data as in B2 and B3 may have higher estimate of biomass due to interpolation of field data. In contrast, maps based on remote sensing data may tend to slightly underestimate the forest biomass due to the scale of analysis and lack of sensitivity to forest biomass (e.g. the saturation effect in optical spectral data). We expect that by improving the scale of maps and the scale of analysis, the emission estimates will also improve. Ideally, a forest biomass map at about 1.0 ha spatial resolution, generated using a combination of remote sensing calibrated using a reasonable network of field plots, as discussed above, and a more direct spatial analysis can readily improve the estimate of the gross emission from deforestation. Such analysis should not be limited to the tropical forests, but include the Brazilian Cerrado and Caatinga biomes, also at risk.

The biomass uncertainty can only partially explain the differences between our estimates and previous studies of carbon losses directly related to deforestation processes in the Brazilian Amazon (Fearnside, 1996; Houghton et al., 2000; DeFries et al., 2002; Achard et al., 2004; Hirsch et al., 2004; Loarie et al., 2009; Potter et al., 2009). Differences may also emerge from processes that a given model represents. For instance, our baseline model balance estimates using Saatch et al. (2007) for the period 2001-2007 are 0.22 $\mathrm{Pg} \mathrm{C} \mathrm{yr}^{-1}$. Loarie et al. (2009) estimated annual carbon emissions of $0.16 \mathrm{Pg} \mathrm{C} \mathrm{yr}^{-1}$ for the same period using the same AGB data; they also use a similar spatially explicit approach based on Houghton et al. (2000) and PRODES deforestation maps. Our primary and secondary forest parameters modified from Houghton et al. (2000) may explain some of the differences (e.g., percFirstYear). But they are possibly explained mostly by the following: (1) The inclusion of belowground biomass (roots decomposition process) in our model. (2) The fact we do not consider cryptic logging and Loarie et al. (2009) adds $7 \%$ to their final estimates to roughly account for this. In a rough comparison, if we remove the BGB contribu-

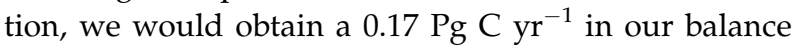
estimate, a closer value to the one estimated by Loarie et al. (2009) for this period. These values are also in general accordance to the ones estimated by DeFries et al. (2002), Achard et al. (2004), and Houghton (2008) for previous time periods.

In contrast, if we use the Nogueira et al. (2008) biomass map, our baseline model estimates increase to $0.27 \mathrm{Pg} \mathrm{C} \mathrm{yr}^{-1}$ for 2001-2007. This value is of the same magnitude as the one estimated by Fearnside (1996), $0.261 \mathrm{Pg} \mathrm{C} \mathrm{yr}^{-1}$, using a similar biomass data source. On the other hand, the values obtained by Potter et al. (2009) are extremely higher: a balance of $0.6 \mathrm{Pg} \mathrm{C} \mathrm{yr}^{-1}$ (2000-2004). However, these estimates use a completely different approach based on the MODIS sensor data and the CASA ecosystem model. For the same period of high deforestation rates, our PF1SF1 model, even if considering the Nogueira et al. (2008) biomass map, estimates a balance of $0.27 \mathrm{Pg} \mathrm{C} \mathrm{yr}^{-1}$. Nevertheless, we consider that given the proper weight to the data sources, compatible methods and processes represented, our estimates are in general accordance with previous work results.

One important difference although is the possibility of representing the primary and secondary forest process parameters in a spatially explicit manner. In the current model we build for the Brazilian Amazon, we spatially explicitly represent the secondary forest dynamics. The parameters we adopted, based on Almeida (2009), capture the current understanding about how the dynamics of the secondary vegetation depends on the degree of occupation of a given area (Alves et al., 2003; Mello et al., 2011; Almeida et al., 2010). In areas with high degree of occupation the amount and lifetime of secondary vegetation is comparatively lower due to the increase in land prices and the influence of agricultural economic activities. As deforestation in Amazonia presents a highly concentrated spatial pattern (Alves, 2002), our baseline secondary vegetation parameters have relatively low values where most deforestation takes place. As a result, according to our baseline SF1 model, the average carbon balance is only 5\% lower than the estimated emissions from primary forest deforestation in 2000-2009. This means that current secondary forest dynamics make a small contribution to the final balance. Previous works have in general estimated a considerably larger impact of secondary vegetation in the regional carbon balance because they have adopted averages that hide this intra-regional variability and overestimate the secondary vegetation area. Hirsch et al. (2004) and Ramankutty et al. (2007), for instance, considered that the percentage of secondary vegetation is one third of the deforested area. Given the large area occupied by the growing vegetation, Ramankutty et al. (2007) estimated that secondary vegetation dynamics reduces carbon emissions in approximately $20 \%$, even when considering that $17 \%$ of the area is re-cleared every year. On the other hand, Hircsh et al. (2004) estimated secondary forests dynamics does not modify the overall estimatives when re-clearing is considered.

In contrast to secondary forest parameters, our baseline model does not adopt spatially explicit parameters to represent the primary forest deforestation process. The percentage of biomass burned in the first year (percFirstYear) is one of the most important variables in the model as it controls the pace of the emissions. However, we did not have a reliable estimative to distribute 
this variable in space. The current baseline model for the Brazilian Amazon adopts an average 50\% value in all cells. This value is larger than the $20 \%$ adopted in previous works (Houghton et al., 2000; Loarie et al., 2009). The higher the parameter the faster the emission estimates reflect deforestation rates temporal evolution. We consider $50 \%$ better captures the heterogeneity of actors and practices in the region. For more accurate intra-regional analysis in future work, INPE_EM allows to represent the spatial distribution of this parameter (as the PF5 submodel illustrates).

\section{A look into the future}

Since 2004, deforestation in the Brazilian Amazon has decreased significantly, from $27772 \mathrm{~km}^{2} \mathrm{yr}^{-1}$ in 2004 to $7000 \mathrm{~km}^{2} \mathrm{yr}^{-1}$ in 2010 (INPE, 2011a,b,c). INPE-EMbased estimates reflect this decreasing rate. The average balance, considering all biomass, drops from 919 (2002-2005) to $702 \mathrm{Tg} \mathrm{CO}_{2} \mathrm{yr}^{-1}$ (2006-2009), or 0.25 to $0.19 \mathrm{Pg} \mathrm{C} \mathrm{yr}^{-1}$. However, the decrease is relatively slower than that the non-process instantaneous emissions model would estimate because this model considers residual emissions distributed over time (slash, wood products, and secondary vegetation). The non-process model would estimate this decrease as being shaper, from 1021(2002-2005) to $528 \mathrm{Tg} \mathrm{CO}_{2} \mathrm{yr}^{-1}$ (2006-2009), or 0.28 to $0.14 \mathrm{Pg} \mathrm{C} \mathrm{yr}^{-1}$, respectively.

In the context of recent global assessments discussed in the Introduction (Le Quéré et al., 2009; Malhi, 2010; Pan et al., 2011), the Brazilian Amazon deforestationdriven $\mathrm{CO}_{2}$ emissions, considering the primary and secondary forest balance of $0.15 \mathrm{PgC}$ in 2009, would represent around $12 \%$ of the global LUC emissions (1.2 PgC according to Le Quéré et al. (2009), for instance). In the context of the overall global $\mathrm{CO}_{2}$ emissions (9.9 PgC according to Le Quéré et al. (2009)), the Brazilian Amazon deforestation contribution would currently represent approximately $1.5 \%$.

However, in spite of this considerable reduction in clear-cut deforestation rates and, consequently, in carbon emissions, there is still an enormous uncertainty about the fate of the forest (Malingreau et al., 2012). The Brazilian government is now committed (both under the UNFCCC framework and through its National Policy on Climate Change) to reducing the Brazilian Amazon clear-cut deforestation by $80 \%$ from the historical rate of $19500 \mathrm{~km}^{2} \mathrm{yr}^{-1}$ by 2020 (Federal Law $12187 / 2009)$. However, in the coming decades, we can expect an increase in food demand associated with global population growth and consumption patterns, which are likely to induce both direct and indirect pressure on the forest (Lapola et al., 2010; Lambin \& Meyfroidt, 2011). Ambitious governmental infrastructure plans also may lead to the occupation of unprotected areas (BRASIL, 2011). There is also an on-going debate about the possible negative impacts of the revision of the Brazilian Forest Act on deforestation and emission rates (Sparovek et al., 2012). In addition to the direct and indirect land-use-change-related threats, possible climate change effects may also affect this stock of carbon through the intensification of droughts (Marengo et al., 2011a,b) and vulnerability to forest fires (Silvestrini et al., 2011), influencing the deforestation frontier itself (Lapola et al., 2011). Recent remote sensing assessments of (primary) forest degradation through selective logging and fire estimated areas of $15987 \mathrm{~km}^{2}$ in 2007, $27417 \mathrm{~km}^{2}$ in 2008 and $13301 \mathrm{~km}^{2}$ in 2009 (INPE, 2011b).

In this context of uncertainty, our results point out relevant aspects about future emission estimatives. First, our analysis reinforces what was already pointed out by Loarie et al. (2009): the deforestation frontier is moving toward areas of higher biomass (Table 4). As deforestation rates decreased so steeply in the last few years, emission rates decreased too. However, if clear-cut deforestation rates begin to rise again in the future, emission estimates can be expected to increase in a nonlinear pattern if compared with similar past deforestation rates. Aragao \& Shimabukuro (2010) highlighted that the amount of carbon stored in the vegetation of the Brazilian Amazon is higher than the total global human-induced $\mathrm{CO}_{2}$ emissions from an entire decade; thus, the implied risks are enormous. Besides, even if clear-cut deforestation remains under control, the forest degradation process discussed above poses a threat. Reliable estimates of emissions related to forest degradation are an open scientific question and current INPE-EM does not account for them. Although spatially explicit information about the location of degraded forest and timber activities are available (Serviço Florestal Brasileiro - SFB, 2010a,b; INPE, 2011b), the scientific challenge resides in understanding the underlying process that leads to forest degradation and the fate of the biomass in those areas. There is a need to understand and correctly represent the following: the land cover change trajectories after exploration (regeneration, fire or clear-cut); the intensity of exploration vs. the level of biomass loss; and the fate of the wood products removed from an area. The INPE-EM framework flexible structure allows the inclusion of new components. As pointed out by Malingreau et al. (2011), attention now must shift away from the strict clear-cut deforestation process to the continuous assessment of degraded forest ecosystems.

The second point relates to our secondary forest component results. As we have already discussed, according to our baseline model the secondary forest 
dynamics has currently a small impact on decreasing carbon emissions due to their short lifetime. However, Almeida et al. (2010) pointed out that secondary forests are potential carbon sinks if they were left alone to regrow. Secondary forests could also play an increasingly important role in maintaining genetic diversity and hydrological function of altered landscapes, but are also being converted to more intensive agricultural uses (Almeida et al., 2010). To explore this hypothesis regarding carbon emissions, we created a hypothetical scenario of a longer secondary vegetation life time and a larger occupied area (percRegrow $=30 \%$, halfLife $=21$ years). Using these parameters the difference between the balance and the primary forest deforestation emissions increases to $15 \%$. This exploratory simulation result suggests that secondary forest dynamics could play a decisive role in the regional $\mathrm{CO}_{2}$ balance in the case the current land-use change trajectories are modified. A scientific question which remains to be explored in future work is how to quantify the impact of different land-use trajectories in the emission estimates. For instance: how the regeneration of part of the illegally deforested areas inside private properties (legal reserves and permanent protection areas) would impact emission estimates in the following decades? The restoration of the legal reserves and permanent protection areas is of the key issues around the possible changes in the Brazilian Forest Act (Sparovek et al., 2012).

In summary, our results for the Brazilian Amazon indicate that efforts to reduce greenhouse gas emissions should continue to focus on improving deforestation control policies to ensure that rates continue to decrease. But they also suggest the importance of creating secondary- and degraded-forest-oriented policies and emission monitoring systems. INPE-EM provides the necessary support to tackle such efforts in terms of carbon emission reductions or increases. The current framework allows the representation of the spatial heterogeneity and complexity of the deforestation process and secondary vegetation dynamics. New components can be added to represent other processes, such as forest degradation. Application models can be created for different regions and scales once reliable biomass and deforestation data are available. Process parameters representing can be spatially distributed, making estimates more reliable in highly heterogeneous and large regions. For smallscale studies, which may be required for local REDD + analysis, the selection and refinement of appropriate parameter values will be critical to obtain unbiased estimates; in the Brazilian Amazon, the most important issue will be the definition of a reliable biomass data source.

\section{Acknowledgements}

For the biomass spatial data, we acknowledge Thelma Krug (MCT, 2010) and Philip Fearnside (Nogueira et al., 2008). For the data preprocessing and database organization, we acknowledge Giovana Espindola, Luciana Soler, Talita Assis, Pedro Valle and André Gavlak. INPE-EM software was developed by the authors using the TerraME modeling environment, available at www.terrame.org. For INPE-EM software maintenance, we acknowledge Talita Assis and Missae Yamamoto. For discussions of the deforestation annual increment correction, we acknowledge Luis Maurano and Marisa Motta (INPE's PRODES Project). Judith J. Hoelzemann and Roberto Araújo are acknowledged for the critical reading of the manuscript. Finally, we thank the Planetary Skin Institute (www.planetaryskin.org) for discussions and for financial support for INPE's CCST LUCC modeling group.

\section{References}

Achard F, Eva HD, Stibig HJ, Mayaux P, Gallego J, Richards T, Malingreau JP (2002) Determination of deforestation rates of the world's humid tropical forests. Science, 297, 999-1002.

Achard F, Eva HD, Mayaux P, Stibig HJ, Belward A (2004) Improved estimates of net carbon emissions from land cover change in the tropics for the 1990s. Global Biochemical Cycles, 18, GB2008, doi: 10.1029/2003GB002142.

Achard F, DeFries F, Eva HD, Hansen M, Mayaux P, Stibig HJ (2007) Pan-tropical monitoring of deforestation. Environmental Research Letters, 2, 045022.

Aguiar APD, Câmara G, Escada MIS (2007) Spatial statistical analysis of land-use determinants in the Brazilian Amazonia: exploring intra-regional heterogeneity. Ecological Modelling, 209, 169-188.

Almeida C (2009)Estimativa da área e do tempo de permanência da vegetação secundária na Amazônia legal por meio de imagens Landsat/TM.INPE, São José dos Campos, 2009; (INPE-15651-TDI/1429).

Almeida C, Valeriano DM, Escada MIS, Rennó C (2009) Estimativa de área de vegetação secundária na Amazônia Legal Brasileira. Acta Amazonica, 40, 285-298.

Almeida A, Stone T, Vieira ICG, Davidson E (2010) Non-Frontier deforestation in the Eastern Amazonia. Earth Interactions, 14, 1-15.

Alves DS (2001) O Processo de desflorestamento na Amazônia. Parcerias Estratégicas. $12,259-275$.

Alves DS (2002) Space-time dynamics of deforestation in Brazilian Amazonia. International Journal of Remote Sensing, 23, 2903-2908.

Alves DS, Escada MIS, Pereira JLG, Linhares CA (2003) Land use intensification and abandonment in Rondônia, Brazilian Amazônia. International Journal of Remote Sensing, 24, 899-903.

Alves DS, Morton DC, Batistella M, Roberts DA, Souza C (2009) The changing rates and patterns of deforestation and land use in Brazilian Amazonia. In: Amazonia and Global Change, Geophysical Monograph Series, Vol 186 (eds Keller M, Bustamante M, Gash J, Silva Dias P), pp. 11-23. AGU, Washington, DC, doi: 10.1029/ 2008GM000722

Aragao L, Shimabukuro YE (2010) The incidence of fire in Amazonian Forests with implications for REDD. Science, 328, 1275-1278.

Araújo R, Lená P (2010) Da predação à sustentabilidade na Amazônia: a difícil metamorfose. In: Desenvolvimento Sustentável e Sociedades na Amazônia, Vol 1, 1st edn (eds Araújo Santos R, Léna P) (Org.), pp. 11-50. MPEG/CNPq/PPG7, Belém, 2010.

Asner GP, Broadbent EN, Oliveira PJC, Keller M, Knapp DE, Silva JNM (2006) Condition and fate of logged forests in the Brazilian Amazon. Proceedings of the National Academy of Sciences of the United States of America, 103, 12947-12950.

Asner GP, Powell GV, N , Mascaro J et al. (2010) High-resolution forest carbon stocks and emissions in the Amazon. Proceedings of the National Academy of Sciences of the United States of America, 107, 16732-16737.

Becker B (2004) Amazônia: geopolítica na virada do III milênio. Rio de Janeiro, Garamond.

BRASIL (2011) Programa de Aceleração do Crescimento: $3^{\circ}$ Balanço Completo (outubrodezembro 2011 - ano 1). Available at: http://www.pac.gov.br/ (accessed 27 July 2012)

Broich M, Stehman SV, Hansen MC, Potapov P, Shimabukuro, YE (2009) A comparison of sampling designs for estimating deforestation from landsat imagery: 
a case study of the brazilian legal amazon. Remote Sensing of Environment, 113, 2448-2454.

Carneiro T (2006) Nested-CA: A Foundation for Multiscale Modeling of Land Use and Land Change. PhD Thesis, INPE, São José dos Campos, São Paulo, Brazil.

Carvalho JA, Costa FS, Veras CAG, Sandberg DV, Alvarado EC, Gielow R, Santos JC (2001) Biomass fire consumption and carbon release rates of rainforest-clearing experiments conducted in northern Mato Grosso, Brazil. Journal of Geophysical Research, 106, 17877-17887.

Clark DB, Clark DA (2000) Landscape-scale variation in forest structure and biomass in a tropical rain forest. Forest Ecology and Management, 137, 185-198.

Costa FA (2004) PATH dependency e a transformação agrária do bioma amazônico: o sentido econômico das capoeiras para o desenvolvimento sustentável. Novos Cadernos NAEA, 7, 111-158. ISSN 1516-6481.

Costa FA (2008) Trajetórias tecnológicas como objeto de política de conhecimento para a Amazônia: uma metodologia de delineamento. Revista Brasileira de Inovações, 8, 35-86.

Costa FA (2009) Desenvolvimento agrário sustentável na Amazônia: trajetórias tecnológicas, estrutura fundiária e institucionalidade. In: Um projeto para a Amazônia no século 21: desafios e contribuições (ed. Becker B), pp. 215-363. Centro de Gestão e Estudos Estratégicos, Brasília.

DeFries RS, Houghton RA, Hansen MC, Field CB, Skole D, Townshend J (2002) Carbon emissions from tropical deforestation and regrowth based on satellite observations for the 1980s and 1990s. Proceedings of the National Academy of Science, 99, 14256-14261.

Dubayah RO, Sheldon SL, Clark DB, Hofton MA, Blair JB, Hurtt GC et al. (2010) Estimation of tropical forest height and biomass dynamics using lidar remote sensing at La Selva, Costa Rica. Journal of Geophysical Research, Biogeosciences, 115, GE00E09, doi: 10.1029/2009JG000933.

Espindola GM, Aguiar AP, Pebesma E, Câmara G, Fonseca L (2011) Agricultural land use dynamics in the Brazilian Amazon based on remote sensing and census data Applied Geography, 32, 240-252, doi: 10.1016/j.apgeog.2011.04.003

Fearnside P (1996) Amazonian deforestation and global warming: carbon stocks in vegetation replacing Brazil's Amazon forest. Forest Ecology and Management, 80, $21-34$.

Fearnside PM (2000) Global warming and tropical land-use change: greenhouse gas emissions from biomass burning, decomposition and soils in forest conversion, shifting cultivation and secondary vegetation. Climatic Change, 46, 115-158.

Fearnside PM, Graça PMLA, LealFilho N, Rodrigues FJA (2001) Burning of Amazonian rainforests: burning efficiency and charcoal formation in forest cleared for cattle pasture near Manaus, Brazil. Forest Ecology and Management, 146, 115 128.

Fearnside PM, Nogueira EM, Nelson BW, Franca MB, Oliveira ACA (2008) Tree height in Brazil's 'arc of deforestation': shorter trees in south and southwest Amazonia imply lower biomass. Forest Ecology and Management, 255, 2963-2972.

Foley JA, Asner GP, Costa MH et al. (2007) Amazonia revealed: forest degradation and loss of ecosystem goods and services in the Amazon Basin. Frontiers in Ecology and the Environment, 5, 25-32.

Hansen M, Shimabukuro Y, Potapov P, Pittman K (2008a) Comparing annual Modis and Prodes forest cover change data for advancing monitoring of brazilian forest cover. Remote Sensing of Environment, 112, 3784-3793.

Hansen MC, Stehman SV, Potapov PV et al. (2008b) Humid tropical forest clearing from 2000 to 2005 quantified by using multitemporal and multiresolution remotely sensed data. Proceedings of the National Academy of Sciences of the United States of America, 105, 9439-9444.

Harris NL, Hagen S, Saatchi SS et al. (2012) Baseline map of carbon emissions from deforestation in tropical regions. Science, 336, 1573-1576, doi: 10.1126/science. 1217962.

Heath L, Maltby V, Miner R, Skog K, Smith J, Unwin J, Upton B (2010) Greenhouse gas and carbon profile of the U.S. forest products industry value chain. Environmental Science and Technology, 44, 3999-4005. Available at: http:dx.doi.org/10.1021/ es902723x.

Hirsch AI, Little WS, Houghton RA, Scott NA, White JD (2004) The net carbon flux due to deforestation and forest re-growth in the Brazilian Amazon: analysis using a process-based model. Global Change Biology, 10, 908-924.

Houghton RA (2003a) Revised estimates of the annual net flux of carbon to the atmosphere from changes in land-use and land management 1850-2000. Tellus, 55(B), 378-390.

Houghton RA (2003b) Why are estimates of the terrestrial carbon balance so different? Global Change Biology, 9, 500-509.

Houghton RA (2008) An Update of Estimated Carbon Emissions from Land Use Change, Typically Updated Every Year. In TRENDS: A Compendium of Data on Global Change,
Oak Ridge National Laboratory, US Department of Energy. Available at: http:// cdiac.ornl.gov/trends/landuse/houghton/houghton.html (accessed 27 July 2012).

Houghton RA, Skole DL, Nobre CA, Hackler JL, Lawrence KT, Chomentowski WH (2000) Annual fluxes or carbon from deforestation and regrowth in the Brazilian Amazon. Nature, 403, 301-304.

Houghton RA, Lawrence KT, Hackler JL, Brown S (2001) The spatial distribution of forest biomass in the Brazilian Amazon: a comparison of estimates. Global Change Biology, 7, 731-746.

IBGE (2006) Censo Agropecuário. Available at: www.ibge.gov.br (accessed 27 July 2012).

INPE (2011a) PRODES - Amazon deforestation database. Available at: www.obt. inpe.br/prodes (accessed 27 July 2012).

INPE (2011b) DEGRAD - Amazon forest degradation database. Available at: www. obt.inpe.br/degrad (accessed 27 July 2012).

INPE (2011c) TerraClass - Amazon land use database Available at: http://www.inpe. br/cra/projetos_pesquisas/terraclass.php (accessed 27 July 2012).

Keller M, Palace M, Asner GP, Pereira R, Silva JNM (2004) Coarse woody debris in undisturbed and logged forests in the eastern Brazilian Amazon. Global Change Biology, 10, 784-795.

Lambin EF, Meyfroidt P (2011) Global land use change, economic globalization, and the looming land scarcity. Proceedings of the National Academy of Sciences of the United States of America, 108, 3465-3472.

Lapola DM, Schaldach R, Alcamo J, Bondeau A, Koch J, Koelking C, Priess JA (2010) Indirect land-use changes can overcome carbon savings from biofuels in Brazil. Proceedings of the National Academy of Sciences of the United States of America, 107, 3388-3393.

Lapola DM, Schaldach R, Alcamo J (2011) Impacts of climate change and the end of deforestation on land use in the Brazilian Legal Amazon. Earth Interactions, 15, 1-29.

Le Quéré C, Raupach MR, Canadell JG et al. (2009) Trends in the sources and sinks of carbon dioxide. Nature Geoscience, 2, 831-836.

Le Toan T, Quegan S, Davidson M, Balzter H, Paillou P, Papathanassiou K et al. (2011) The BIOMASS Mission: mapping global forest biomass to better understand the terrestrial carbon cycle. Remote sensing of environment, 115, 2850-2860.

Loarie SR, Asner GP, Field CB (2009) Boosted carbon emissions from Amazon deforestation. Geophysical Research Letters, 36, L14810, doi: 10.1029/2009GL037526.

Luizão RCC, Luizão FJ, Paiva RQ et al. (2004) Variation of carbon and nitrogen cycling processes along a topographic gradient in a central Amazonian forest. Global Change Biology, 10, 592-600.

Malhi Y (2010) The carbon balance of tropical forest regions, 1990-2005. Current Opinion in Environmental Sustainability, 2, 237-244.

Malhi Y, Wood D, Baker TR et al. (2006) The regional variation of aboveground live biomass in old-growth Amazonian forests. Global Change Biology, 12, 11071138 .

Malingreau JP, Eva HD, Miranda EE (2012) Brazilian Amazon: a significant five year drop in deforestation rates but figures are on the rise again. AMBIO: A Journal of the Human Environment, 41, 309-314, doi: 10.1007/s13280-011-0196-7.

Marengo JA, Tomasella J, Alves LM, Soares WR, Rodriguez DA (2011a) The drought of 2010 in the context of historical droughts in the Amazon region. Geophysical Research Letters, 38, L12703, doi: 10.1029/2011GL047436.

Marengo JA, Tomasella J, Soares WR, Alves LM, Nobre C (2011b) Extreme climatic events in the Amazon basin: climatological and hydrological context of previous floods. Theoretical and Applied Climatology, 85, 1-13.

Martinelli LA, Naylor R, Vitousek PM, Moutinho P (2010) Agriculture in Brazil: impacts, costs, and opportunities for a sustainable future. Current Opinion on Environmental Sustainability, 2, 431-438, doi: 10.1016 j.cosust.2010.09.008.

MCT (2010) Brazilian Ministry of Science and Technology. Brazilian Second National Communication to the United Nations Framework Convention on Climate Change.

Mello A, Iwama Y, Alves DS (2011) Secondary vegetation dynamics in the Brazilian Amazon based on thematic mapper imagery. Remote Sensing Letters, 2, 189-194.

MMA (2011) Brazilian Ministry of Environment. Plano Anual de Outorga Florestal (PAOF). Available at: www.sfb.gov.br/(accessed 27 July 2012)

Morton DC, DeFries RS, Shimabukuro YE et al. (2006) Cropland expansion changes deforestation dynamics in the southern Brazilian Amazon. Proceedings of the National Academy of Sciences of the United States of America, 103, 14637-14641.

Nepstad D, Verissimo A, Alencar A et al. (1999) Large-scale impoverishment of Amazonian forests by logging and fire. Nature, 398, 505-508.

Nogueira EM, Fearnside PM, Nelson BW, Franca MB (2007) Wood density in forests of Brazil's 'arc of deforestation': implications for biomass and flux of carbon from land-use change in Amazonia. Forest Ecology and Management, 248, 119-135. 
Nogueira EM, Fearnside PM, Nelson BW, Barbosa RI, Keizer EWH (2008) Estimates of forest biomass in the Brazilian Amazon: new allometric equations and adjustments to biomass from wood-volume inventories. Forest Ecology and Management, 256, 1853-1867.

Ometto JP, Nobre AD, Rocha HR, Artaxo P, Martinelli LA (2005) Amazonia and the modern carbon cycle: lessons learned. Oecologia, 143, 483-500.

Ometto JP, Aguiar APD, Martinelli LA (2011) Amazon deforestation in Brazil: effects, drivers and challenges. Carbon Management, 2, 575-585.

Palace M, Keller M, M , Asner GP, Silva JNM, Passos C (2007) Necromass in undisturbed and logged forests in the Brazilian Amazon. Forest Ecology and Management, 238, 309-318.

Pan Y, Birdsey RA, Fang J, Houghton R, Kauppi PE et al. (2011) A large and persistent carbon sink in the world's forests. Science, 333, 988-993.

Perz SG, Skole DL (2003) Social determinants of secondary forests in the Brazilian Amazon. Social Science Research, 32, 25-60.

Phillips OL, Baker TR, Arroyo L, et al. (2004) Pattern and process in Amazon forest dynamics, 1976-2001. Philosophical Transactions of the Royal Society, Series B, 359, 381-407.

Potter C, Klooster S, Genovese V (2009) Carbon emissions from deforestation in the Brazilian Amazon Region. Biogeosciences, 6, 2369-2381.

Ramankutty N, Gibbs HK, Achard F, Defries R, Foley JA, Houghton RA (2007) Challenges to estimating carbon emissions from tropical deforestation. Global Change Biology, 13, 51-66.

Saatch SS, Houghton RA, Alvalá R, Soares JV, Yu Y (2007) Distribution of aboveground live biomass in the Amazon basin. Global Change Biology, 13, 816-837.

Saatchi SS, Harris NL, Brown S et al. (2011a) Benchmark map of forest carbon stocks in tropical regions across three continents. Proceedings of the National Academy of Sciences of the United States of America, 108, 9899-9904.

Saatchi S, Marlier M, Clark D, Chazdon R, Russell A (2011b) Impact of spatial variability of forest structure on radar estimation of aboveground biomass. Tropical Forests Remote Sensing of Environment, Special Issue: VEG3D, 115, 2836 2849.

Serviço Florestal Brasileiro-SFB (2010a). Florestas do Brasil em resumo-2010: dados de 2005-2010. Serviço Florestal Brasileiro-SFB, Brasília.

Serviço Florestal Brasileiro-SFB; Instituto do Homem e Meio Ambiente da Amazônia -Imazon. (2010b). Atividade Madeireira na Amazônia Brasileira: produção receitas e mercados. Serviço Florestal Brasileiro-SFB, Belém.

Shugart H, Saatchi S, Hall F (2010). A primer on the structure of forest and it measurements from space, JGR. Biogeosciences, 115, G00E13, doi: 10.1029/2009J G000995.

da-Silva RP (2007) Alometria, estoque e dinâmica da biomassa de florestas primárias e secunda 'rias na região de Manaus(AM). PhD Thesis, Instituto Nacional de
Pesquisas da Amazônia/Fundação Universidade Federal do Amazonas, Manaus, Amazonas, Brazil.

Silver WL, Thompson AW, McGroddy ME et al. (2005). Fine root dynamics and trace gas fluxes in two lowland tropical forest soils. Global Change Biology, 11, 290-306, doi: $10.1111 /$ j.1365-2486.2005.00903.x.

Silvestrini R, Soares-Filho B, Nepstad D, Coe M, Rodríguez H, Assunção R (2011) Simulating fire regimes in the Amazon in response to climate change and deforestation. Ecological Applications, 21, 1573-1590.

Sparovek G, Berndes G, Barretto AG, Klug IL (2012) The revision of the Brazilian Forest Act: increased deforestation or a historic step towards balancing agricultural development and nature conservation? Environmental Science \& Policy, 16, 65-72, doi: 10.1016/j.envsci.2011.10.008.

Tardin AT, Lee DCL, Santos RJR et al. (1980) Subprojeto Desmatarnento, Convênio IBDF/ CNPq-INPE 1979. Instituto Nacional de Pesquisas Espaciais (INPE), São José dos Campos, São Paulo.

Walker RT, Moran E, Anselin L (2000) Deforestation and cattle ranching in the Brazilian Amazon: external capital and household processes. World Development, 28, 683-699.

van der Werf GR, Morton DC, DeFries RS, Giglio L, Randerson JT, Collatz GJ, Kasibhatla PS (2009) Estimates of fire emissions from an active deforestation region in the southern Amazon based on satellite data and biogeochemical modelling. Biogeosciences, 6, 235-249.

\section{Supporting Information}

Additional Supporting Information may be found in the online version of this article:

File S1. Modeling the spatial and temporal heterogeneity of deforestation-driven carbon emissions: the INPE-EM framework applied to Brazilian Amazonia.

Please note: Wiley-Blackwell are not responsible for the content or functionality of any supporting materials supplied by the authors. Any queries (other than missing material) should be directed to the corresponding author for the article. 


\title{
SUPPORTING INFORMATION
}

\section{"Modeling the spatial and temporal heterogeneity of deforestation-driven carbon emissions: the INPE-EM framework applied to Brazilian Amazonia"}

\author{
Global Ghange Biology
}

Ana P. D. Aguiar, Jean P. Ometto, Carlos Nobre, David M. Lapola, Claudio Almeida, Ima C. Vieira, João V. Soares, Regina Alvala, Sassan Saatchi, Dalton Valeriano, Juan C. Castilla-Rubio

\section{S.1 Annual deforestation rate}

According to the procedure described by PRODES project (available at http://www.obt.inpe.br/prodes/metodologia.pdf ), there are a number of considerations that must be taken into account in order to estimate an accurate annual rate of deforestation (total area of clear-cut deforestation that happens in given year) to the whole Brazilian Amazon. These considerations are related to the different acquisition dates among the several LANDSAT/TM images used to build the satellite mosaic of the whole region. These intrinsic differences are due to the satellite revisiting cycle as well as to cloud coverage, which can prevent the use of a set of images acquired in nearby dates. To completely cover the Brazilian Amazon, approximately 230 LANDSAT TM scenes are required (Fig. S.1). In order to provide a more accurate estimate of the overall rate of deforestation, the date of August $1^{\text {st }}$ is adopted as a reference. In general lines, the amount of deforestation identified in each LANDSAT/TM is corrected summing or subtracting the estimated amount deforested per day in relation to the dereference date. In this sense, the PRODES procedure computes a local rate for each LANDSAT/TM scene according to the acquisition date. The sum of the local rates for every LANDSAT/TM scene that cover the rainforest area of the Brazilian Amazon is the estimated rate that year. The same procedure is also applied for each Federative State. 


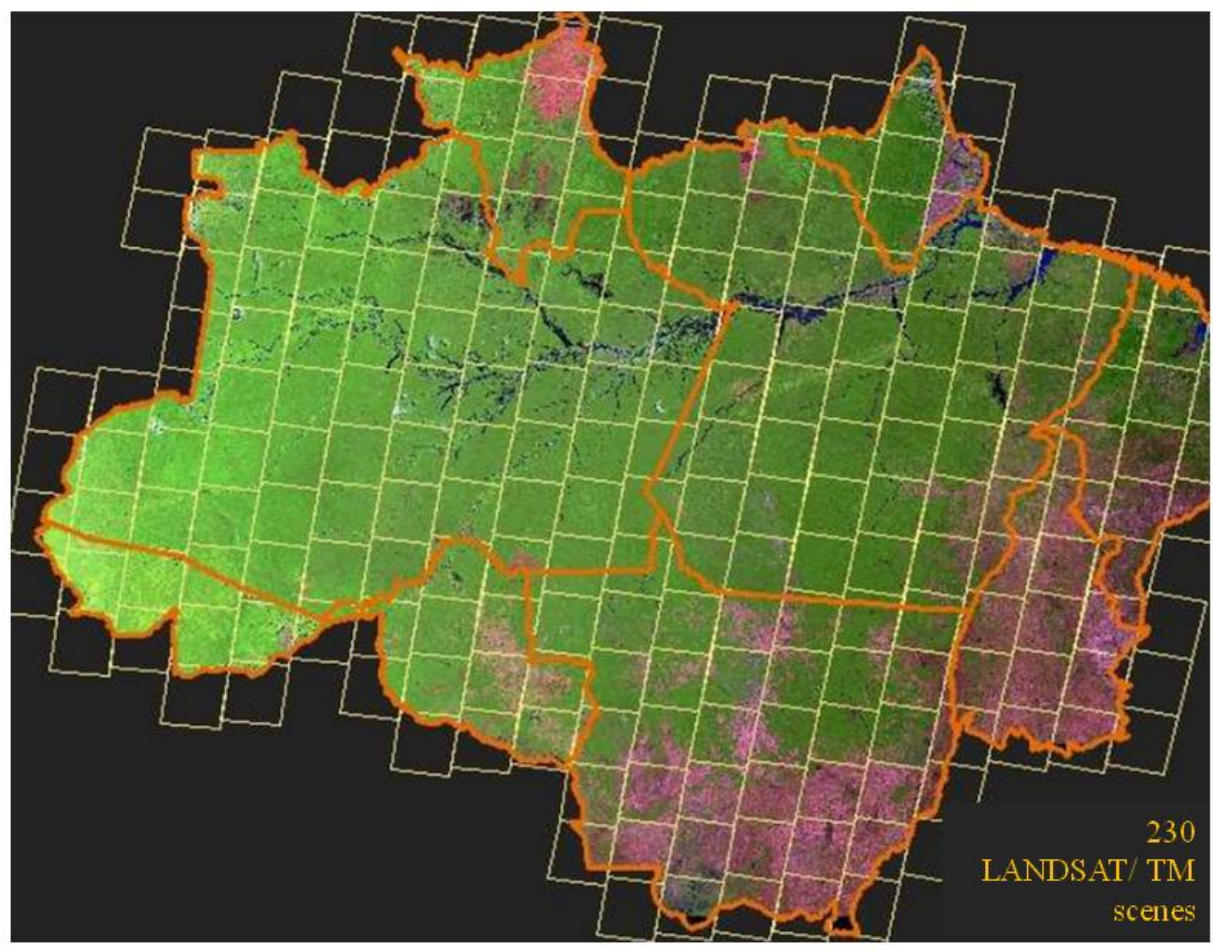

Figure S.1. Landsat TM scenes required to cover the Brazilian Amazon.

Depending on the year, this procedure may yield significant differences between the simple sum of cell increments and the official estimated rate. These discrepancies were larger between 2002 and 2006, as Fig. S.2 illustrates. In more recent assessments, multiple satellite sensors have been combined to minimize cloud cover problems, making the time interval between the scenes smaller.

Because of these methodological aspects of the PRODES project in computing the yearly deforestation rates, the estimation of greenhouse gases (GHG) emissions based on the raw PRODES land cover maps (also available at http://www.obt.inpe.br/prodes/) can result in disparate results in a given year, if compared to GHG emissions estimates that take into account only the overall deforestation rate. Therefore, we developed an adjustment procedure to guarantee that INPE-EM gives compatible estimates in the spatial and non-spatial modes, while preserving the original spatially distributed information as much as possible. 
(a)

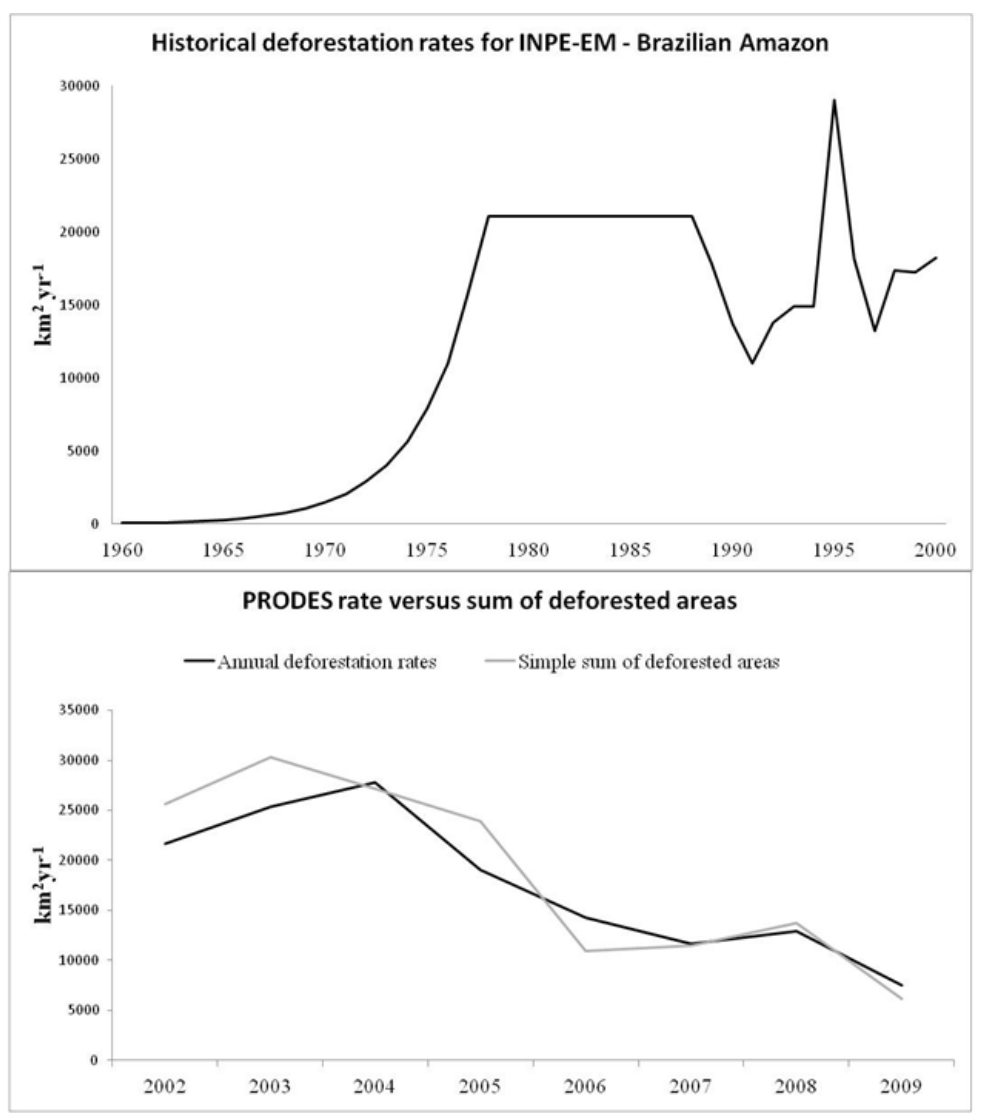

Figure S.2. (a) Historical Brazilian Amazon deforestation rates according to the PRODES system; (b) difference between PRODES rates and the sum of the area of new clearings identified in each scene.

The procedure (repeated every year) is as follows: (a) First, we compute, for each $25 \times 25 \mathrm{~km}^{2}$ cell and for each LANDSAT/TM scene, the total amount of new deforestation identified in the raw PRODES raster map for a given year. (b) Then, for each LANDSAT/TM scene, we compute the difference between (a) and the local rate for that scene (available at http://www.obt.inpe.br/prodes/rates/). (c) Finally, this local difference (positive or negative) is distributed evenly in the cells with increment greater than zero covering that scene. As a result, the sum of our $25 \times 25 \mathrm{~km}^{2}$ cell deforest attributes match the official annual PRODES rate (Fig. S.1.2), while maintain the spatial distribution information of the newly deforested areas (see Fig. 3 in the article). 


\section{S.2 Biomass data sources}

Chave et al. (2005) highlighted four sources of uncertainty for aboveground biomass (AGB) estimates in tropical forests, including the following: (a) error in tree measurements, (b) the choice of the allometric model relating AGB to other tree dimensions, (c) the size of the study plot, and (d) the representativeness of the study plot to the larger forested area. These authors report an uncertainty in AGB estimates that varies from 4 to $20 \%$ depending on the sample size and, most importantly, the choice of the allometric model and indicate that estimates of wood density can contribute to the reduction of ABG estimate uncertainty (Chave et al., 2005). In this paper, we selected four recent AGB data sources, which are briefly described below:

- B1 - Saatchi et al. (2007) reported a method based on remote sensing, environmental variables and more than 500 plot measurements of forest biomass distributed over the Brazilian Amazonia basin. According to their estimates, AGB is higher in northern and western Amazonia, generally above $300 \mathrm{Mgha}^{-1}$. In eastern Amazonia, where most of the deforestation is historically concentrated (Alves 2001, 2002), AGB ranges from 150 to $300 \mathrm{Mgha}^{-1}$ (Fig. 3a). The authors reported greater than $80 \%$ accuracy for their method using a cross-validation approach with the field plots. The spatial analysis of error using bootstrapping approach suggested that the uncertainty in northern and western Amazonia where field plots were scare exceeded $40 \%$.

- B2 - Nogueira et al. (2008), studying wood density distribution in a high deforestation risk area, proposed a $7 \%$ reduction in the general accepted wood density value for the region $\left(0.69 \mathrm{gcm}^{-3}\right)$, updating the biomass distribution data from Fearnside et al. (1997). In eastern Amazonia, AGB ranges from 250 to 300 $\operatorname{Mgha}^{-1}$ (Fig. 3a). The range of variation is smaller than in Saatchi et al. (2007), but the values are considerably higher (Fig. 3b). 
- B3 - MCT (2010): The third biomass map used in the present study is derived from the Brazilian National Communication to the United Nations Framework Convention on Climate Change (UNFCCC). This estimate is based on the project RADAM Brazil, which extensively mapped the Brazilian Amazonia region from 1971-1986 at a 1:1,000,000 scale. This project identified eight forest classes in the region and inventoried areas from 0.5 to 1.0 ha, measuring all trees with a $\mathrm{DBH}$ (diameter at breast height) greater than $38 \mathrm{~cm}$. Based on these measurements, the MCT (2010) used allometric equations proposed by Higuchi et al. (1998) to estimate forest biomass. The biomass correction for measurements smaller than 38 cm DBH was corrected according to the distribution histogram produced by RADAM (Brazil, 2006). As in Saatchi et al. (2007), AGB ranges from 150 to 250 $\mathrm{Mgha}^{-1}$ in most of the Eastern Region except for the northern part of Pará State (Fig. 3c). This data source apparently has some inconsistencies derived from the original RADAM vegetation maps, but these problems do not affect the area known as the arc of deforestation in southeastern Amazonia, which concentrates most of the process. Thus, we included this map in our analysis to compare our model results with the estimates of the Brazilian National Communication to the UNFCCC.

- B4 - Saatchi et al. (2011): In a global analysis, these authors used ground information on forest structures and biomass in different forest types (old growth tropical forest, woodland savanna, dry forest, and recovering forest) and more than 3 million remotely measured forest height and biomass at footprints of about 0.25 ha derived from the Geoscience Laser Altimeter System (GLAS) LiDAR onboard ICESAT satellite. These data were used to map the above- and belowground forest biomass in several regions, including the tropical forest of Brazilian Amazonia, at a $1 \mathrm{~km}$ spatial resolution. The uncertainty was assessed by validating the results with 
ground observations and an independent set of LiDAR derived biomass across tropical forests (Saatchi et al., 2011, Supporting Information).

As Fig. 4 in our paper illustrates, the four maps are quite distinct in terms of their magnitude and spatial distribution. In addition to these variations among data sources, the level of uncertainty in each map must also be considered in the emission estimates. Saatchi et al. (2007) reports values from 0 to greater than $400 \mathrm{Mgha}^{-1}$ classified into eleven categories; we considered the medium value in each interval to compute the average and the minimum and maximum interval values as an error range. Saatchi et al. (2011) report spatially explicit uncertainty values, which we also consider in our estimates.

\section{S.3 Supplementary references}

Chave J, Andalo C, Brown S, et al. (2005) Tree allometry and improved estimation of carbon stocks and balance in tropical forests, Oecologia, 145(1), 87-99.

Higuchi N, Santos J, Ribeiro RJ, Minette L, Biot Y (1998) Biomassa da Parte Aérea da Vegetação da Floresta Tropical Úmida de Terra-firme da Amazônia Brasileira, Acta Amazonica, Manaus, v. 28, n.2, p. 153-166, 1998. 